\title{
Trace element chemistry and U-Pb dating of zircons from oceanic gabbros and their relationship with whole rock composition (Lanzo, Italian Alps)
}

\author{
M.-A. Kaczmarek · O. Müntener · D. Rubatto
}

Received: 2 February 2007/ Accepted: 30 July 2007 / Published online: 16 October 2007

(c) Springer-Verlag 2007

\begin{abstract}
The U-Pb ages and the trace element content of zircon $\mathrm{U}-\mathrm{Pb}$ along with major and trace element whole rock data on gabbroic dikes from the Lanzo lherzolitic massif, N-Italy, have been determined to constrain crustal accretion in ocean-continent transition zones. Three $\mathrm{Fe}-\mathrm{Ti}$ gabbros were dated from the central and the southern part of the massif providing middle Jurassic ages of $161 \pm 2$, $158 \pm 2$ and $163 \pm 1 \mathrm{Ma}$, which argue for magmatic activity over few millions of years. Zircon crystals are characterized by high but variable $\mathrm{Th} / \mathrm{U}$ ratios, rare earth element patterns enriched in heavy rare earths, pronounced positive $\mathrm{Ce}$ and negative Eu-anomalies consistent with crystallization after substantial plagioclase fractionation. The zircon trace element composition coupled with whole rock chemistry was used to reconstruct the crystallization history of the gabbros. A number of gabbros crystallized in situ, and zircon precipitated from trapped, intercumulus
\end{abstract}

Communicated by J. Hoefs.

Electronic supplementary material The online version of this article (doi:10.1007/s00410-007-0243-3) contains supplementary material, which is available to authorized users.

M.-A. Kaczmarek ( $₫)$

Institute of Geology, University of Neuchâtel, rue Emile Argand, Neuchâtel 2007, Switzerland

e-mail: Mary-alix.kaczmarek@unine.ch

M.-A. Kaczmarek · O. Müntener

Institute of Mineralogy and Geochemistry,

University of Lausanne, Anthopole,

Lausanne 1015, Switzerland

D. Rubatto

Research School of Earth Sciences,

The Australian National University,

Canberra, ACT 0200, Australia liquid, while other gabbros represent residual liquids that were extracted from a cumulus pile and crystallized along syn-magmatic shear zones. We propose a model in which the emplacement mechanism of gabbroic rocks in oceancontinent transition zones evolves from in situ crystallization to stratified crystallization with efficient extraction of residual liquid along syn-magmatic shear zones. Such an evolution of the crystallization history is probably related to the thermal evolution of the underlying mantle lithosphere.

Keywords Zircon · Oxyde gabbros ·

Trace element geochemistry - Peridotite - Lanzo massif . Piemont-Ligurian ocean · SHRIMP · U-Pb dating

\section{Introduction}

The processes and mechanisms determining accretion of oceanic crust widely differ among the global mid-ocean ridge systems, and are mainly dependant on spreading rates (Bown and White 1994; Dick 1994; Dick et al. 2000; Langmuir et al. 1992). At spreading rates lower than about $20 \mathrm{~mm} /$ year (ultra-slow spreading ridges), additional parameters such as the thermal structure and the composition of the underlying mantle dramatically affect crustal production rates (Dick et al. 2003). Similar observations are made for the accretion of oceanic crust in oceancontinent transition zones (Müntener and Manatschal 2006; Tucholke et al. 2007). Ophiolites in general do not provide direct constraints on spreading rates. However, the predominance of lherzolite and harzburgite subtypes (Nicolas 1989) has been taken as a proxy for magma production rates from which paleo-spreading rates might be inferred. 
Results from a variety of studies indicate that the (ultra-) slow spreading oceanic crust of the Jurassic-Cretaceous Piemont-Ligurian ocean is dominated by the emplacement of small-scale gabbroic bodies of generally less than $500 \mathrm{~m}$ in thickness (Desmurs et al. 2002), intruded into mantle rocks that are partly sub-continental in origin (Decandia and Elter 1972; Piccardo 1976). This association of subcontinental mantle and gabbroic rocks is covered either by small volumes of effusive basaltic rocks (pillow lavas, pillow breccias, Desmurs et al. 2002; Dietrich 1969) or directly by mid-Jurassic sediments. The overall volume of basaltic rocks is small and discontinuous. Geochronological data across the remnants of the Piemont-Ligurian ocean suggest that the gabbroic bodies crystallized over a short period of time, from $\sim 170$ to $150 \mathrm{Ma}$ (Rubatto et al. 1998; Rubatto and Hermann 2003; Schaltegger et al. 2002; Tribuzio et al. 2004). However, there is some discrepancy between ages inferred from $\mathrm{Sm}-\mathrm{Nd}$ isochrons and ages determined by $\mathrm{U}-\mathrm{Pb}$ on zircon. $\mathrm{Sm}-\mathrm{Nd}$ mineral isochrons have been determined on a few Mg-gabbro samples from Ligurian gabbros ranging from $\sim 180$ to $164 \mathrm{Ma}$ (Rampone et al. 1998; Tribuzio et al. 2004). U-Pb ages on zircon, however, indicate generally younger ages ranging from 166 to 148 (Bill et al. 1997; Costa and Caby 2001; Rubatto et al. 1998; Rubatto and Hermann 2003; Schaltegger et al. 2002). However, few attempts have been made so far to quantify the duration of MOR-type magmatism in a spatially restricted area.

In this paper, we present the results of $\mathrm{U}-\mathrm{Pb}$ age determinations on zircons from mafic rocks distributed over more than $20 \mathrm{~km}^{2}$ within the Lanzo peridotite massif, in order to constrain the time interval over which gabbro emplacement was active. We combine whole rock major and trace element data, with zircon trace element chemistry, to discuss possible crystallization mechanisms of zircon in gabbroic rocks. We infer, that over time, the formation of highly differentiated, zircon-saturated liquid evolved from dominantly intercumulus, in situ crystallization, to extraction along shear zones, leaving at depth the primitive cumulates from where such fractionated liquids originated. This means that the stratification of mafic oceanic crust is an evolving process that likely depends on the thermal evolution of the oceanic lithosphere during late rifting to (ultra-)slow seafloor spreading.

\section{Geological setting}

The Lanzo massif is located in the Western Alps, northwest of Torino (Italy), and is bounded to the north by the continental Sesia-Lanzo zone and to the east by the Piemont-Ligurian ophiolite zone (Fig. 1). The northern part

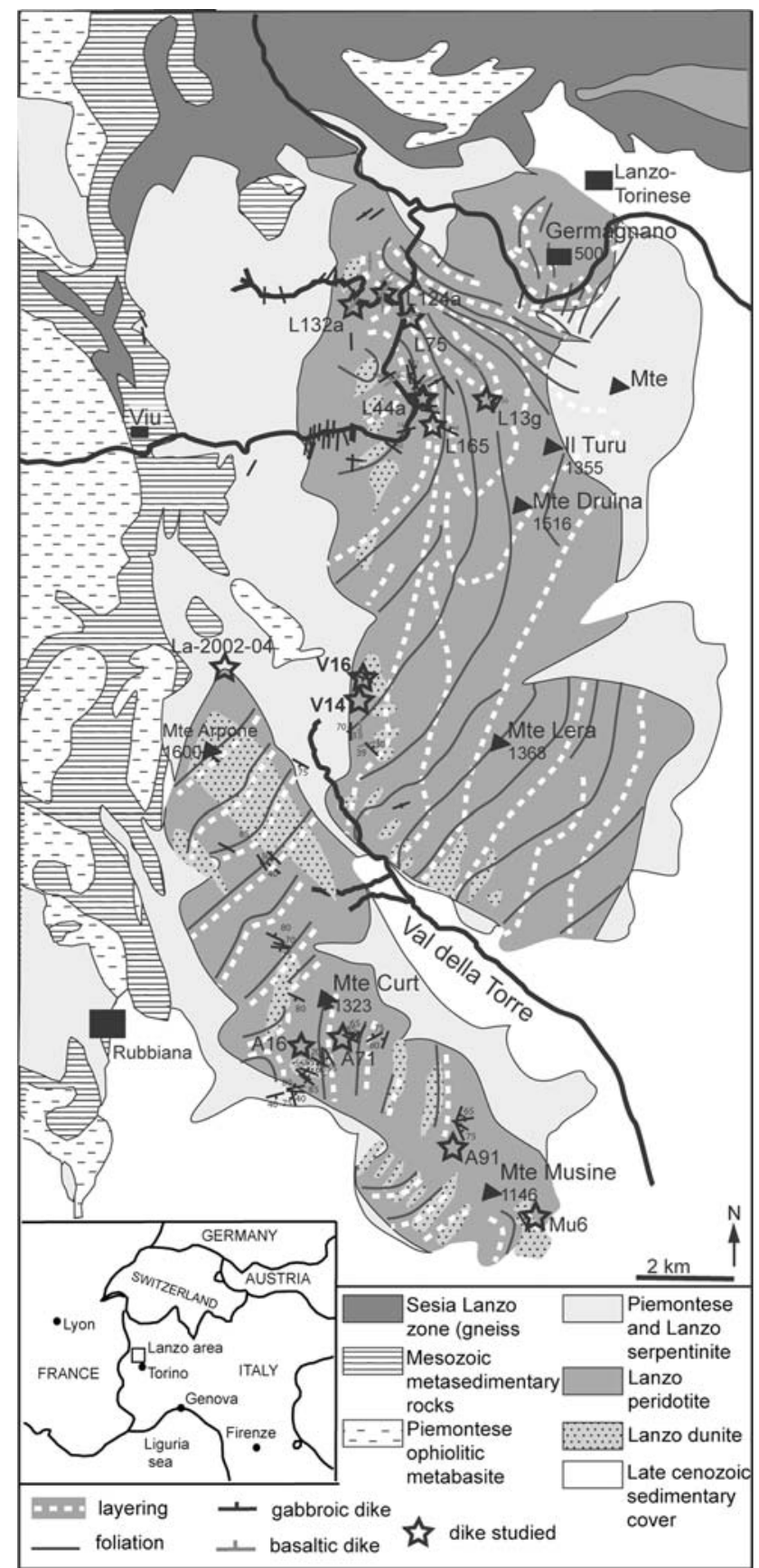

Fig. 1 Geological map of the Lanzo massif and the surrounding areas (compiled after Boudier 1972, 1978; Boudier and Nicolas 1972; Pelletier 2003; Pognante 1989). The location of gabbroic and basaltic dikes is indicated with black stars. Additional gabbro dikes and basaltic rocks are compiled from Boudier (1972), (1978), Pognante (1989) and Pelletier (2003)

of the massif consists of peridotite surrounded by strongly foliated serpentinites, which are the combined result of ocean-floor alteration and Alpine metamorphism. Many gabbroic dikes were metamorphosed and rodingitized during ocean floor alteration and Alpine metamorphism. 
However, in less serpentinized areas gabbroic dikes were partially transformed into eclogites during Alpine subduction in Alpine times (Kienast and Pognante 1988; Pelletier and Müntener 2006). Locally the massif is overlain by minor ophicarbonates, MORB type volcanic rocks and metasediments (Lagabrielle et al. 1989; Pelletier and Müntener 2006). The core of the Lanzo massif is dominated by fertile plagioclase lherzolite and minor volumes of spinel harzburgite and dunite (Boudier 1972, 1978; Piccardo et al. 2004). The peridotite body is characterized by a high temperature foliation and pyroxenite layering (Boudier 1978, Fig. 1). In addition, the massif contains numerous intrusive rocks (Boudier 1978; Boudier and Nicolas 1972) that may be classified into three groups according to their relative timing (Boudier and Nicolas 1972): (1) an "indigenous" group which consist of plagioclase to gabbroic veinlets, frequently occurring in "echelon", and thin millimeter to centimeter scale olivine gabbro dikes. (2) an "intrusive" group consisting of olivine-gabbros, gabbronorite to ferro-gabbros and rare plagiogranites occurring as several meters thick dikes. (3) Fine grained gabbro dikes parallel to swarms of basaltic dikes and cutting across the gabbros of the "intrusive" group and the high temperature foliation. Recent studies refined this model and proposed a conceptual model from porous to focused melt flow to explain the various igneous features in the Lanzo peridotite (Müntener and Piccardo 2003; Müntener et al. 2005; Piccardo et al. 2004): (a) a pervasive porous melt flow leading to the formation of impregnated peridotites; (b) focused porous flow where melt transport is mainly focused in replacive harzburgites and dunites; (c) initial crystallization and formation of megacrysts and small dikes corresponding to the "indigenous" group of Boudier and Nicolas (1972); and (d) ubiquitous formation of km-scale, discordant gabbroic and basaltic dikes. Previous studies (Bodinier 1988; Bodinier et al. 1986; Pognante et al. 1985) indicate that gabbro and basaltic dikes are derived from T-MORB to T- to $\mathrm{N}$-MORB type magmas from the north to the south, respectively, and are compositionally similar to ophiolitic basalts of the Ligurian, Western and eastern central Alps (Beccaluva et al. 1984; Bill et al. 2000; Desmurs et al. 2002).

The Lanzo massif is considered a part of the lithospheric mantle exhumed at the ocean floor during opening of the Jurassic-Piedmont Ligurian ocean (Lagabrielle et al. 1989; Pognante et al. 1985). Recent studies demonstrate that the presence of a high-temperature mantle shear zone between the north and the central part of the massif is related to rapid mantle exhumation. This exhumation is presumably active during the earliest stages of the formation of embryonic oceanic crust (Kaczmarek and Müntener 2007).
Field occurrence of mafic dikes in the Lanzo massif

The Lanzo massif contains numerous intrusive rocks ranging from coarse-grained troctolites, olivine-gabbros to fine-grained basaltic dikes. A geological map illustrates the heterogeneous spatial distribution of gabbroic and basaltic dike and their relative orientation with respect to the hightemperature foliation in the peridotite (Fig. 1). In the northern part of the massif, gabbro dikes are not observed. From the central to the southern part of the massif, mafic dikes are progressively more abundant, increase in size and are preferentially found toward the west (Fig. 1). The structurally earliest gabbros are represented by small dikelets or lenses of gabbro in the central part of the massif within granular lherzolite (Fig. 2a). Gabbro to gabbronorite dikelets are $1-4 \mathrm{~cm}$ thick and rarely exceed $10-40 \mathrm{~cm}$ in length. In the south part of the massif, dikelets are more abundant than in the central part and are composed of cmscale clinopyroxene and plagioclase (Fig. 2b). The dikelets show fuzzy contacts with the country-rock peridotite and can be surrounded by a dunitic zone (Fig. 2b) where euhedral to subhedral spinel is preserved. The presence of dikelets and mega-crystals of clinopyroxene associated to plagioclase in dunite are precursors to gabbroic dikes (Müntener and Piccardo 2003; Müntener et al. 2005; Piccardo et al. 2004). The dikelets of cm-scale with fuzzy contacts are clearly different to intrusive dikes, which show sharp and discordant contacts with the pyroxenite layering and the high-temperature foliation. The thickness of gabbros varies from 5 to $40 \mathrm{~cm}$ (locally exceeding $1 \mathrm{~m}$ ) while basalts vary between 15 and $30 \mathrm{~cm}$ (Fig. 2c, d). Gabbro dikes are generally thicker in the southern part of the massif $(10 \mathrm{~cm}$ to several meters, Fig. $2 \mathrm{~d}$, e). Most of the dikes are troctolite, to olivine-gabbros, to kaersutite and $\mathrm{Fe}-\mathrm{Ti}$ gabbro with rare plagiogranites. In the southern part of the massif, gabbroic dikes may be flanked by symmetric dunitic zones, which are proportional in size to the gabbro dikes (Fig. 2e). Basaltic dikes are rare throughout the massif and mostly present in the western central part (close to the shear zone in Fig. 1) where they cut and have sharp contact with the undeformed to mylonitic peridotite (Fig. 2d).

\section{Petrography of zircon bearing gabbro dikes}

Five samples from the Lanzo peridotitic massif (four ferrogabbros and one plagiogranite) were selected for geochronological investigations because of their high modal zircon content. Two gabbros (L165 and V14) and the plagiogranite (V16) were sampled in the central part and the two other gabbros (A71 and A91) are from the south part of the massif (for location see Fig. 1). 
Fig. 2 Field photographs of gabbroic and basaltic dikes. a Dikelets of gabbro-norite within lherzolite from the central part of the Lanzo massif (diameter of coin is, $2 \mathrm{~cm}$ ); b Dikelet of gabbro within dunite from the south part of the Lanzo massif; c Gabbroic dikes cross cut the pyroxenite layering and the high-temperature foliation in the central part of the massif; $\mathbf{d}$ The peridotite is cross cut by a $\mathrm{Fe}-\mathrm{Ti}$ gabbro (V14) and a gabbro body (La2002-2006) which in turn is cross cut by a basaltic dike (La2002-07). Central part of the massif (for location see Fig. 1); and e Gabbroic dike with symmetric dunite zones from the southern part of the massif
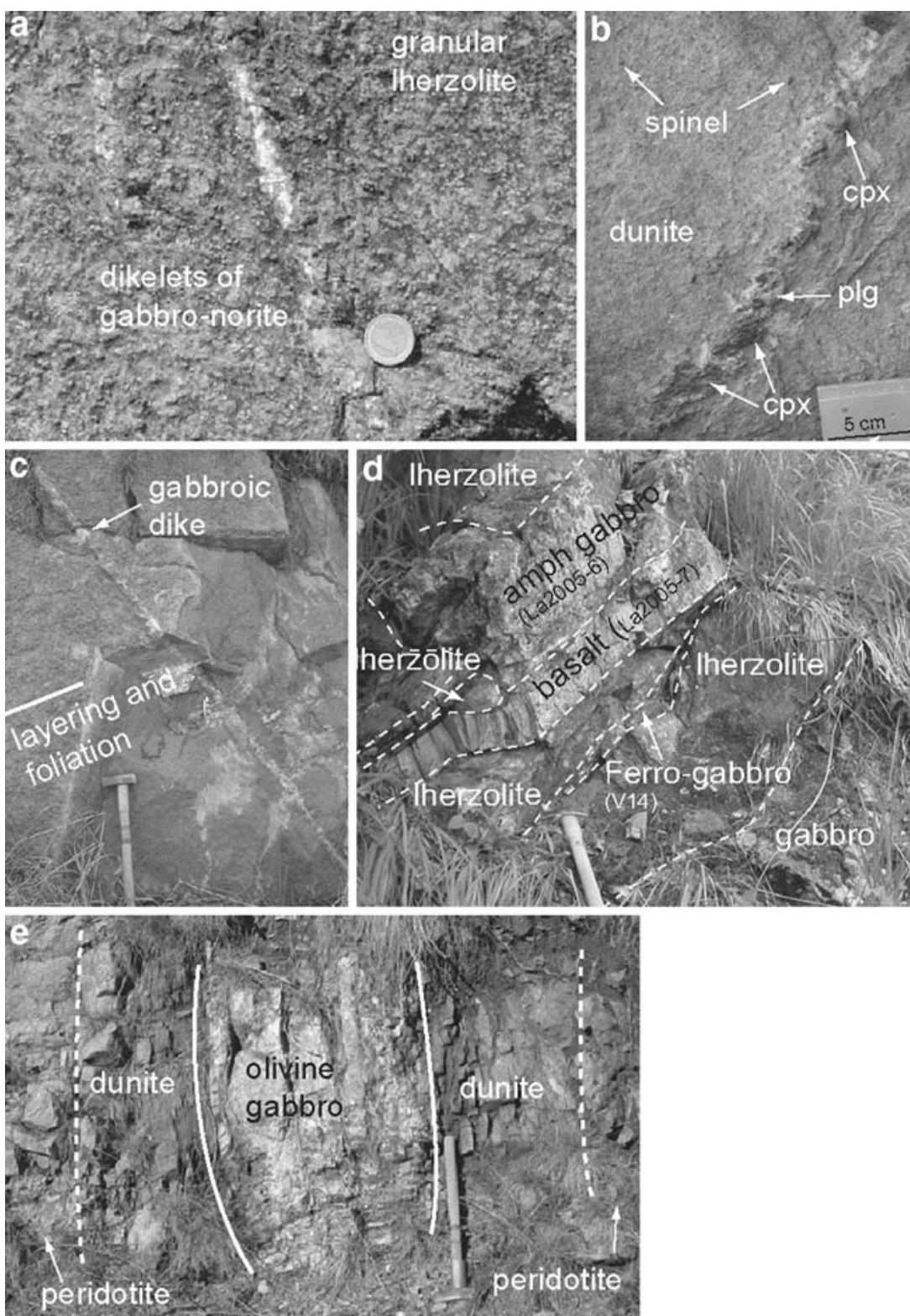

The Fe-gabbro L165 is located in the footwall of a kmscale shear zone that separates the north from and the central part of the Lanzo massif (Fig. 1). The outcrop is located along the road between the villages of Castagnole and Maddalene (Fig. 2), where ferro-gabbros, several olivine gabbro dikes and a basaltic dike cut the peridotite (Kaczmarek and Müntener 2005). The $5 \mathrm{~cm}$ thick dike has a sharp contacts to the host peridotite. The dike contains a mylonitic shear zone in the central part underlined by the crystallization of oriented kaersutite, plagioclase and ilmenite (Fig. 3a). Two parts can be distinguished: (1) a light colored domain, which corresponds to former plagioclase, now present as a fine-grained symplectite of jadeite and quartz, associated with zoisite and garnet; (2) a brown to greenish domain mainly composed of magmatic amphibole and ilmenite. The amphibole is partially replaced by a corona of white or green amphibole and ilmenite, which is probably exsolved from the primary Ti-rich hornblende (Fig. 3c). The minerals are parallel to the shear zone in the central part of the sample and indicate shearing close to the boundary (Fig. 3a). The shear zone concentrates brown, Ti-rich hornblende, ilmenite, zircon and apatite (Fig. 3a, c). Hypidiomorphic zircon crystals are concentrated in the central shear zone and generally range from 100 to $250 \mu \mathrm{m}$ in size with some smaller grains $(20 \mu \mathrm{m})$ also found.

Sample A91 is from the southern part of the Lanzo massif (Fig. 1) and was sampled in a gabbro-rich area (1 km long) containing numerous mostly undeformed troctolite and olivine-gabbros, and several $\mathrm{Fe}-\mathrm{Ti}$ gabbros. 

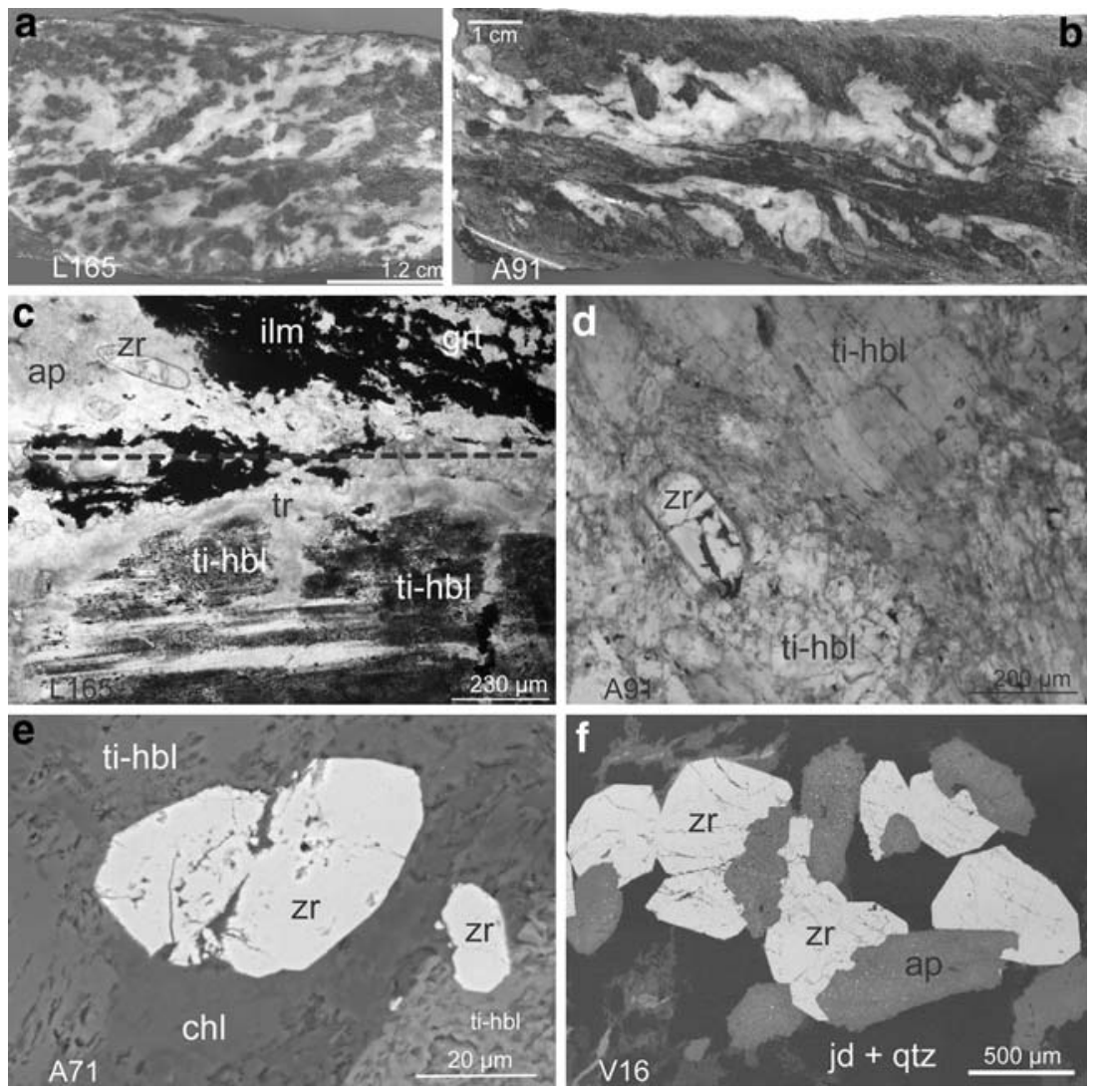

Fig. 3 Macro- and micro-scopic textures of gabbros: a Ferro-gabbro

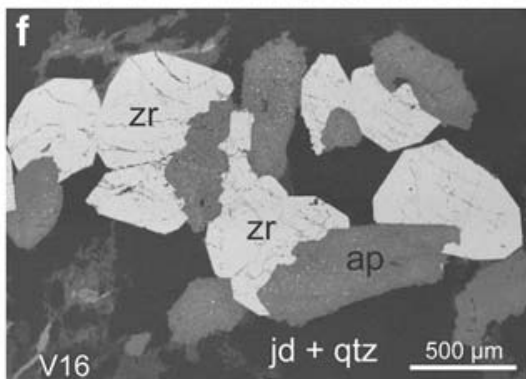

(L165) with a central fine-grained shear zone (dashed line; see

crystal associated with hornblende, in the central part of the sample (plane polarized light); e SEM image of idiomorphic zircon crystals (sample A71); f SEM image of plagiogranite (V16) with euhedral zircon and apatite, embedded in a matrix of metamorphic jadeite and quartz. Abbreviations are: Ti-hbl Ti-rich hornblende, ilm ilmenite, ap apatite, $z r$ zircon, tre tremolite; grt garnet, $c h l$ chlorite, jad jadeite, $q t z$ quartz

c Microphotograph (plane polarized light) of the shear zone withir sample L165 (dashed line) with enrichment of ilmenite, apatite and zircon; d Photomicrograph of sample A91 showing a large zircon

The dike is $\sim 7 \mathrm{~cm}$ thick and shows a syn-magmatic shear zone in the central part (Fig. 3b, d). Ti-hornblende, ilmenite, apatite and zircon are concentrated within the shear zone with large T-hornblende crystals concentrated at the border. The white domains (Fig. 3d) represents former igneous plagioclase and now consists of metamorphic jadeite + quartz symplectites associated with ilmenite and garnet. The white matrix contains garnet, zoisite, tremolite, titanite, chlorite and plagioclase. Zircons are concentrated in the shear zone (grain size between 60 and $250 \mu \mathrm{m}$ ) suggesting localized flow of $\mathrm{Zr}$-saturated, differentiated melt.

V14a is a hornblende-gabbro ( $7 \mathrm{~cm}$ thickness) cross cutting a peridotite associated with a gabbro body (Fig. 2 e). The sample is composed of cm-scale, magmatic Tihornblende with ilmenite inclusions parallel to the contact with the host peridotite and surrounded by a matrix of granoblastic hornblende ( $\mathrm{mm}$ grain size). Small zircons and apatite $(\sim 20 \mu \mathrm{m})$ are found in the granoblastic hornblende

matrix. The white domains are ghosts of igneous plagioclase now transformed into jadeite + quartz symplectites plus zoisite and/or clinozoisite.

The ferro-gabbro A71 (60 cm thickness) shows a mineralogical variation expressed by a higher concentration of $\mathrm{Fe}-\mathrm{Ti}$ minerals (e.g., ilmenite) close to the walls. Similar to smaller Fe-Ti gabbros, this sample is composed of white and black spots containing both magmatic and metamorphic parageneses. The white areas, are composed of a matrix of chlorite and chloritoid, and contain relics of rutile rimmed by titanite. The black areas are composed of centimetric ilmenite replaced along grain boundaries by zoisite, garnet and chlorite. The relict magmatic paragenesis is represented by igneous clinopyroxene and euhedral zircons (20-150 $\mu \mathrm{m}$ in length Fig. 3e).

$\mathrm{V} 16 \mathrm{~b}$ is a white to greenish fine-grained meta-plagiogranite about $8 \mathrm{~cm}$ thick that has sharp contacts with the host peridotite. The meta-plagiogranite is composed of a matrix of omphacite, zoisite, chlorite, clinozoisite, and 
symplectite areas of jadeite + quartz. The sample is extremely rich in euhedral zircons (Fig. 3f) intergrown with inclusion-rich apatite. The presence of allanite, rutile and omphacite in the matrix suggests partial recrystallization at high-pressure conditions.

\section{Analytical techniques}

The samples were crushed with an agate mill to reduce trace element contamination. Whole rock glasses were prepared with the addition of Li-Tetraborate (dilution at 1:10). Gabbros and basalts were analyzed by wavelengthdispersive X-ray fluorescence spectroscopy (XRF, Phillips PW 1404) at the University of Fribourg (Switzerland). Trace element precision is generally better than $5 \%$. All trace element analyses for basalts and $\mathrm{Fe}-\mathrm{Ti}$ gabbros were obtained by Laser Ablation ICP-MS on the glasses using a pulsed $193 \mathrm{~nm}$ Excimer Laser system (Lambda Physik, Geolas $200 \mathrm{M}$ ), coupled with an ICP-MS (Perkin Elmer DRC 6200), at the University of Lausanne, with operating conditions of $27 \mathrm{kV}$, and $10 \mathrm{~Hz}$ repetition rate, yielding a flux of ca $12 \mathrm{~J} / \mathrm{cm}^{2}$ on the ablation site. Helium was used as a carrier gas. The NIST 610 glass was chosen as an external standard, and $\mathrm{Ca}$ as the internal standard. BCR2 basaltic glass was used to monitor the reproducibility and accuracy of the system.

Olivine-gabbros and troctolite whole rock trace elements (REE, $\mathrm{Cs}, \mathrm{Rb}, \mathrm{Th}, \mathrm{U}, \mathrm{Nb}, \mathrm{Ta}, \mathrm{Sr}, \mathrm{Zr}$, and $\mathrm{Hf}$ ) were analyzed by a VG-PQ2 Turbo + inductively coupled plasma-mass spectrometer (ICP-MS) at ISTEEM (Université Montpellier II, Montpellier, France) and are reported in eTable 2. REE, $\mathrm{Cs}, \mathrm{Rb}, \mathrm{Pb}, \mathrm{Th}, \mathrm{U}, \mathrm{Sr}, \mathrm{Zr}$, and Hf concentrations were determined by external calibration following the $\mathrm{HF} / \mathrm{HClO}_{4}$ dissolution and analytical procedure described in detail by Ionov et al. (1992). To avoid memory effects due to the intake of concentrated $\mathrm{Nb}-\mathrm{Ta}$ solutions in the instrument, $\mathrm{Nb}$ and $\mathrm{Ta}$ concentrations were determined by using $\mathrm{Zr}$ and $\mathrm{Hf}$, respectively, as internal standards. This technique is an implementation to ICP-MS analysis of the method described by Jochum et al. (1990). Detection limits obtained by long-term analyses of chemical blanks at ISTEEM can be found in Ionov et al. (1992).

For zircon separation all samples were crushed and sieved to less than $250 \mu \mathrm{m}$. Zircons were separated according to magnetic properties and density and finally selected by hand picking. Zircons separated were mounted on a $25 \mathrm{~mm}$ epoxy discs and polished down to expose the grain centers. The internal zoning was investigated by a cathodoluminescence (CL) detection system at the Electron Microscope Unit at the Australian National University (ANU) with a HITACHI S2250-N scanning electron microscope operating at $15 \mathrm{kv}$ accelerating potential, $\sim 60 \mu \mathrm{A}$ current and $20 \mathrm{~mm}$ working distance.

Trace element analyses on zircons were performed by Laser Ablation ICP-MS at the Research School of Earth Sciences, ANU using a pulsed 193-nm ArF Excimer laser, with $100 \mathrm{~mJ}$ energy at a repetition rate of a $5 \mathrm{~Hz}$, coupled to an Agilent 7500 quadrupole ICP-MS (Eggins et al. 1998). During the time-resolved analysis, the contamination from inclusions, fractures and zones of different composition was detected by monitoring several elements. It might, however, not have been possible to eliminate all contaminations from micro inclusions whose signal was spread over the entire analysis. In specific cases it was chosen to present analyses containing inclusions in order to identify the compositions of the inclusions and/or have information on the elements not affected by the inclusions (e.g., Y will not be affected by a plagioclase inclusion). Analysis spot size was 24 or $32 \mu \mathrm{m}$ in diameter. External calibration was performed relative to NIST 612 glass using the concentration given in Pearce et al. (1996). Internal standard was Si.

$\mathrm{U}-\mathrm{Th}-\mathrm{Pb}$ analyses of zircons were performed with a sensitive high resolution ion microprobe (SHRIMP II) at the ANU using a beam size of $\sim 25 \mu \mathrm{m}$. Analytical procedures were similar as described by Compston et al. (1984). The measured $\mathrm{U}-\mathrm{Pb}$ ratios were corrected using the standard zircon TEM (417 Ma, Black et al. 2003), which was analyzed each fourth analysis. A zircon of knows composition (SL13) has been used to determine the $\mathrm{U}$ content of zircon. The data were corrected for common $\mathrm{Pb}$ on the basis of the measured ${ }^{207} \mathrm{~Pb} /{ }^{206} \mathrm{~Pb}$ ratios as described in Compston et al. (1992) and assuming a common $\mathrm{Pb}$ composition according to the model of Stacey and Kramers (1975). The analytical uncertainty in the reproducibility of the $\mathrm{U}-\mathrm{Pb}$ age of the standard was between 2.2 and $2.4 \%(2 \sigma)$. Age calculations were done using the software Isoplot/Ex (Ludwig 2003). Mean ages are intercept ages in uncorrected ${ }^{207} \mathrm{~Pb} /{ }^{206} \mathrm{~Pb}$ vs ${ }^{238} \mathrm{U} /{ }^{206} \mathrm{~Pb}$ (Tera Wasserburg) diagrams and are given at $95 \%$ confidence level.

\section{Whole rock major and trace element geochemistry}

The whole rock analyses were performed on discordant mafic dikes, on the entire compositional spectrum of oceanic gabbros, ranging from troctolite (L44a, La2002-4) to olivine gabbro (L13 g, Mu6, A16) to Fe-Ti gabbro (A91, L165, A71, and La2005-6). We also analyzed one plagiogranite (V16), and two basalts (L132a and La2005-7), although these rocks are strongly overprinted by Alpine metamorphism. Results on major and trace element chemistry are summarized in eTables 1 and 2, additional 
analyses might be found elsewhere (Bodinier et al. 1986; Piccardo et al. 2007; Pognante et al. 1985).

\section{Major and minor elements}

The chemical evolution of the Lanzo gabbros is well reflected by the variation of bulk $\mathrm{Mg \#}$ (calculated as molar $\mathrm{Mg} / \mathrm{Mg}+\mathrm{Fe}_{\text {tot }}$, all $\mathrm{Fe}$ as $\mathrm{Fe}^{2}$ ). Some gabbros have elevated $\mathrm{Mg} \#$ at relatively high $\mathrm{Zr}$ content indicating substantial exchange with the host peridotite (eTable 1). The $\mathrm{Al}_{2} \mathrm{O}_{3}$ content varies from $\sim 12$ to $21 \mathrm{wt} \%$ and is highest for troctolite (27.84 wt\%). Basalts, ferro-gabbros and amphibole gabbro have high $\mathrm{TiO}_{2}$ contents compared to olivinegabbros and troctolite, but olivine-gabbros are particularly rich in $\mathrm{Ni}$ (368 and $524 \mathrm{ppm}$ ).

Ferro-gabbros have high $\mathrm{Zr}$ contents (150-314 ppm) and an exceptionally high $\mathrm{Zr}$ value is reported for the plagiogranite $(3,352 \mathrm{ppm}$, not shown in Fig. 4b). In contrast to ferro-gabbros, the olivine gabbro and troctolite have low $\mathrm{Zr}$ contents $(<10 \mathrm{ppm})$, in agreement with $\mathrm{Zr}$ concentration known from previous studies of the Lanzo gabbros (Bodinier et al. 1986; Pognante et al. 1985). The Mg\# shows a large variation: from 0.47 to 0.88 , with the higher $\mathrm{Mg} \#$ and $\mathrm{Al}_{2} \mathrm{O}_{3}$ contents are observed in the olivine gabbro, troctolite and plagiogranite (eTable 1). The $\mathrm{TiO}_{2}$ increase reflects the differentiation of the different gabbro types, from olivine-gabbros and troctolite $(0.05-0.21 \mathrm{wt} \%)$ to ferro-gabbros (1.99-4.65 wt\%, Fig. 4c and eTable 1). The plagiogranite shows low concentration of $\mathrm{TiO}_{2}$

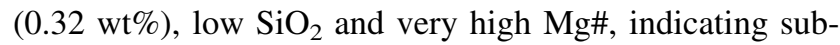
stantial metasomatic exchange with the peridotite, either during ocean floor alteration, or during high-pressure metamorphism. The composition in $\mathrm{Ti}$ and $\mathrm{P}$ of troctolite, olivine-gabbros and plagiogranite are depleted compared to ferro-gabbros (eTable 1 and Fig. 4). The general trend, from olivine-gabbros to ferro-gabbros, shows a $\mathrm{Zr}$, Ti, Y enrichment and a Ni decrease.

The basaltic dikes show little variation in terms of their Mg\# (0.55-0.62), except for the rodingite sample (L124a) which has a Mg\# of 0.68 (eTable 1) and contain elevated $\mathrm{Zr}$ contents (110-279 ppm, Fig. 4b). The $\mathrm{Al}_{2} \mathrm{O}_{3}$ and $\mathrm{TiO}_{2}$ contents are similar to basalts from the Western Alps and from the Lanzo massif (Bodinier et al. 1986; Pognante
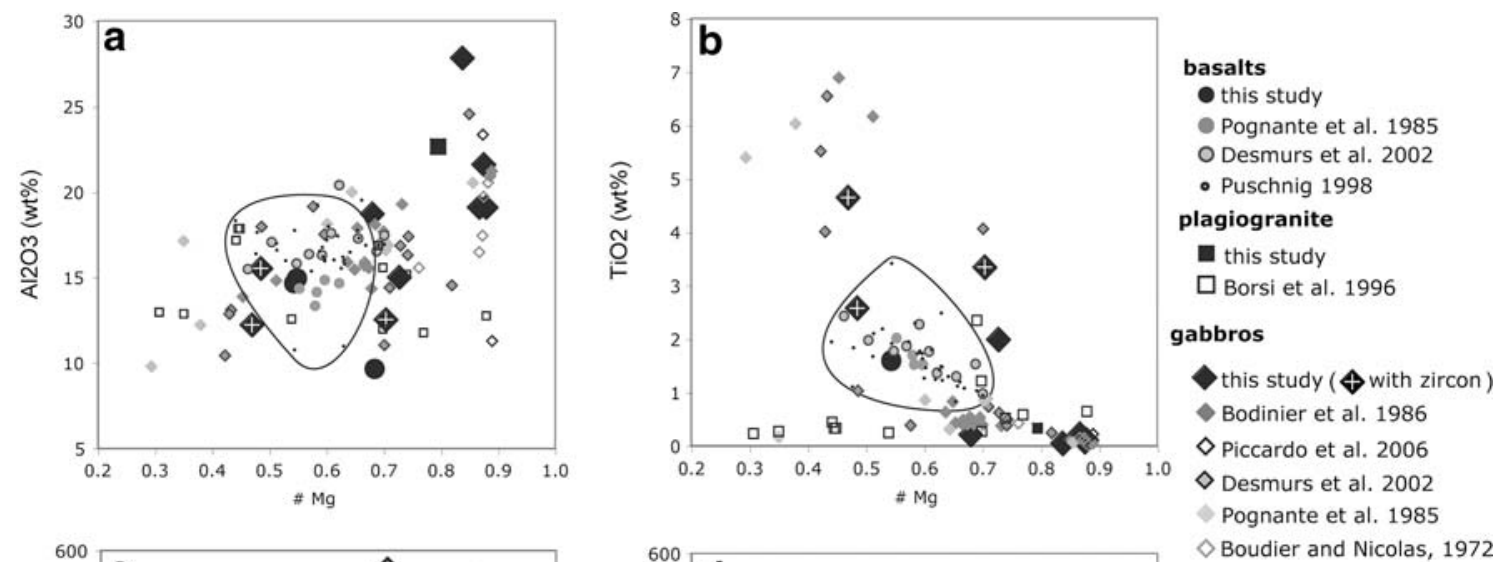

$\checkmark$ Boudier and Nicolas, 1972
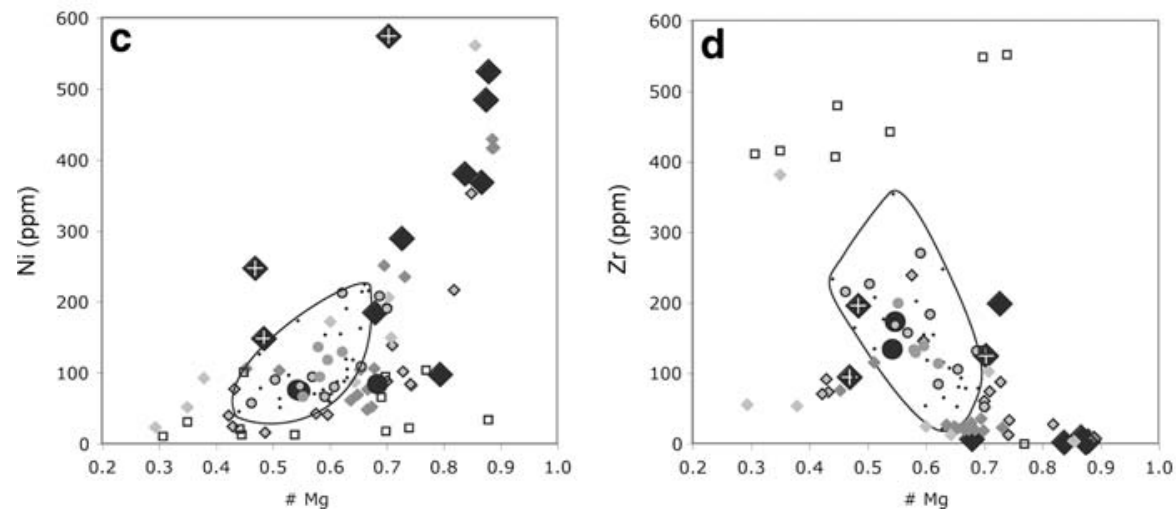

Fig. 4 Major and trace element variation diagrams of mafic rocks from the Lanzo massif: a $\mathrm{Mg \#}$ (molecular $\mathrm{Mg} /\left(\mathrm{Mg}+\mathrm{Fe}_{\text {tot }}\right)$ ) vs $\mathrm{Al}_{2} \mathrm{O}_{3}$; b $\mathrm{Mg \#}$ vs $\mathrm{TiO}_{2}$; c $\mathrm{Mg \#}$ vs $\mathrm{Ni}$ (ppm); d $\mathrm{Mg \#} \mathrm{vs} \mathrm{Zr}(\mathrm{ppm})$. Additional data from the Lanzo massif are from Boudier and Nicolas
(1972), Piccardo et al. (2007), Bodinier et al. (1986) and Pognante et al. (1985); Additional data from the Alpine-Apennine system are plotted for comparison (Borsi et al. 1996; Desmurs et al. 2002; Puschnig 1998). The black line encloses the basalt field 
et al. 1985, Fig. 4c). The Lanzo basalts display a positive correlation of $\mathrm{Mg \#}$ with $\mathrm{Ni}$ and a negative correlation with $\mathrm{TiO}_{2}$.

\section{Rare earth elements}

Lanzo troctolites to olivine-gabbros display a large positive $\mathrm{Eu}$ anomaly $\left(\mathrm{Eu} / \mathrm{Eu}^{*}=\mathrm{Eu}_{\mathrm{N}} /\left(\mathrm{Sm}_{\mathrm{N}}+\mathrm{Gd}_{\mathrm{N}}\right) / 2\right.$ from 6.8 to 2.0). The positive Eu anomaly illustrates that the Lanzo troctolites and olivine-gabbros are cumulates from which substantial amounts of derivative liquid has been extracted. The $(\mathrm{Ce} / \mathrm{Yb})_{\mathrm{N}}$ varies from $<1$ to 2.8 and suggests variable proportions of clinopyroxene and plagioclase, and possibly variable amounts of trapped liquids, as illustrated by interstitial Ti-hornblende in some samples. The exceptionally high $(\mathrm{La} / \mathrm{Yb})_{\mathrm{N}}$ at very low heavy REE (e.g., $\mathrm{Yb}_{\mathrm{N}}$ : 0.54) indicates plagioclase-rich troctolite layers in some places supporting the cumulate nature of much of the primitive Lanzo gabbros.

$\mathrm{Fe}-\mathrm{Ti}$ gabbros are characterized by a relatively flat REE pattern with a weak fractionation of light to middle REE, and $(\mathrm{Gd} / \mathrm{Yb})_{\mathrm{N}}>1$ (Fig. 5a). The chondrite normalized REE diagram of zircon-bearing rocks highlights two samples (A91 and La2005-6) with a negative Eu anomaly, one sample relatively flat in REE pattern (L165) and one sample with a positive $\mathrm{Eu}$ anomaly (A71, Fig. 5a and eTable 2). From sample A71 to La2005-6, the overall distribution is similar and shows REE enrichment. The $\mathrm{Sr}$ content correlates positively with the $\mathrm{Eu}$ anomalies suggesting that plagioclase controls the Sr budget of the whole rocks (eTable 1).

The plagiogranite is enriched in incompatible elements and has a U-shaped REE pattern with a very low and a pronounced negative Eu anomaly (0.30), indicating plagioclase fractionation prior to crystallization. In addition, the plagiogranite is enriched in HFSE and Sr (Fig. 5a, eTable 1).

Basalt analyses are plotted in Fig. 5b, together with previously published instrumental neutron activation analysis data (Bodinier et al. 1986; Pognante et al. 1985) and compared to other basalt occurrences in the Alps (Desmurs et al. 2002). The basalts from Lanzo are homogeneous in $\mathrm{REE}$, show $(\mathrm{La} / \mathrm{Yb})_{\mathrm{N}}$ close to unity and are analogue to $\mathrm{N}-\mathrm{MORB}$ compositions. The general trend is close to those of ferro-gabbros but the REE content is lower (eTable 2). In contrast to basalts from various places from the Alps (Desmurs et al. 2002) the variation in REE is rather limited and T- to E-MORB compositions have not been found.

\section{Zircon description}

The zircon grains from mylonitic ferro-gabbro L165 are transparent and 200-300 $\mu \mathrm{m}$ in size. They often appear like fragments of larger euhedral crystals. Oscillatory zoning can be present, but the majority of crystals are characterized by irregular sectors with different CL emission or patchy zoning (Fig. 6a). They often present a network of sealed fractures that cut across the zoning and along which low luminescence zircon is present (Fig. 6b).

Fe-gabbro A71 contains transparent light pink zircon fragments between 80 and $400 \mu \mathrm{m}$ in size, which only occasionally preserve pyramidal faces. Growth zoning is rare (Fig. 6c) and most of the crystals are CL-dark and either unzoned (Fig. 6d) or patchy zoned and rich in mineral inclusions (Fig. 6e). In the mylonitic Fe-gabbro A91, zircons are similar to A71 for size and shape, but more often preserve growth zoning. One remarkable zircon from A91 has a more complex structure with a dark center
Fig. 5 Chondrite normalized REE patterns from gabbros a and basalts $\mathbf{b}$ from the Lanzo massif. Additional data from the Lanzo massif are from Bodinier et al. (1986) and Piccardo et al. (2007). $\mathrm{Gd}_{\mathrm{N}}$ values for the data of Bodinier et al. (1986) are interpolated between $\mathrm{Tb}_{\mathrm{N}}$ and $\mathrm{Sm}_{\mathrm{N}}$. Additional data sources are Desmurs et al. (2002) and Beccaluva et al. (1984, grey area). Normalization values for chondrite are taken from Sun and McDonough (1989)

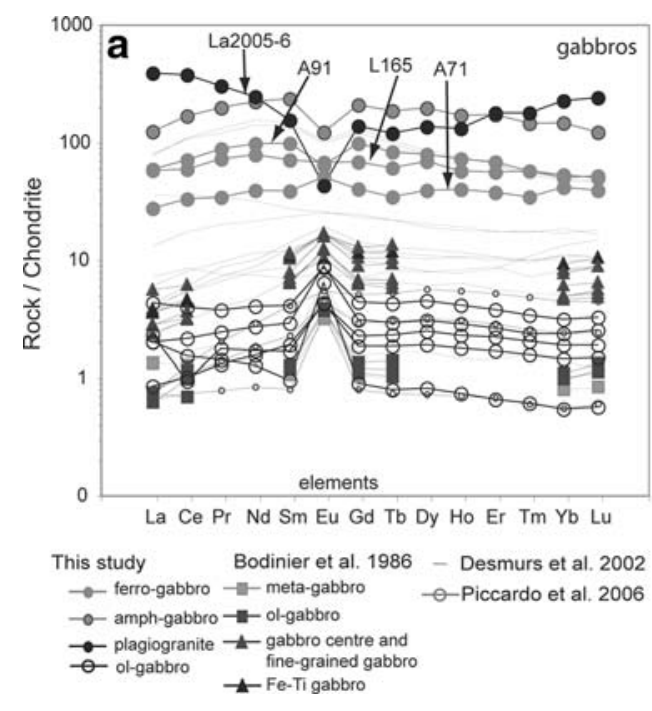




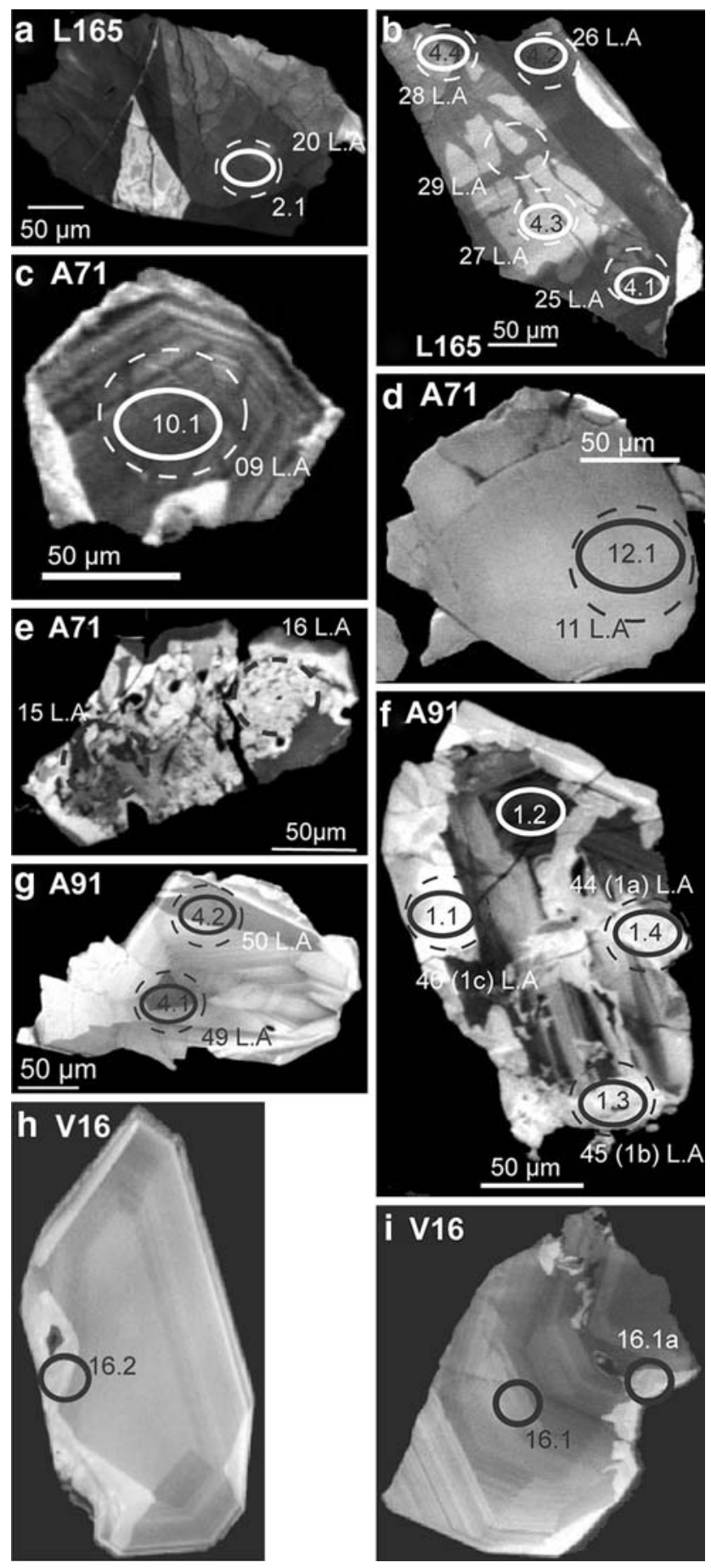

Fig. 6 Cathodoluminescence images of dated zircons from three ferro-gabbros (L165 in a-b, A71 in c-e and A91 in $\mathbf{f}-\mathbf{g}$ ) and the plagiogranite V16 (h-i). Solid circles: SHRIMP analyses and numbering associated (e.g. 2.1); dotted circles: LA-ICPMS analyses and numbering associated (e.g. $20 \mathrm{LA}$, and reported in eTable 3). See text for discussion

with remnants of growth zoning that is cross cut by fractures and surrounded by an unzoned, bright rim (Fig. 6f). Several larger crystal display patchy zoning (Fig. 6g), but the majority of grains corresponds to small, unzoned fragments (ca. $100 \mu \mathrm{m}$ ), with moderate CL emission. The plagiogranite (V16) contains euhedral zircons (100$500 \mu \mathrm{m})$ that are clear and transparent with a well-developed oscillatory-sector growth zoning (Fig. 6h-i).

\section{Zircon composition}

Zircon crystals from three of the dated samples were analyzed for their trace element composition by LA-ICPMS (eTable 3; Figs. 7, 8). Th and U contents were also measured during SHRIMP analysis (Table 1) and values are generally comparable to LA-ICPMS results. Occasionally, higher Th and $\mathrm{U}$ contents were measured by SHRIMP because the limited volume of the analysis allowed targeting small CL-dark and thus $\mathrm{U}$ and Th-rich domains.

Zircon in the three samples have $\mathrm{U}$ and Th contents from low (a few ppm) to moderate (several hundreds of ppm), which vary significantly even within a sample, particularly in L165 and A71. Zircons in gabbro A91 are the most homogeneous with the lowest contents in $\mathrm{Th}, \mathrm{U}$ and P. Zircons from all samples contain comparable average $\mathrm{Ti}$ concentrations around 15-25 ppm. However, similarly to $\mathrm{U}$ and $\mathrm{Th}$, significant variations in $\mathrm{Ti}$ are detected in zircons from sample A71 and A91 where an extreme value of $145 \mathrm{ppm}$ was measured.

Zircons from sample A71 show a strong variation in a number of elements including $\mathrm{P}, \mathrm{Ti}, \mathrm{Sr}, \mathrm{Y}$, and $\mathrm{Yb}$. Some of these variations might be due to the presence of micro inclusions of apatite ( $\mathrm{Sr}$ and $\mathrm{P}$ ) and/or xenotime (P, Y and $\mathrm{Yb})$. In fact, analyses performed on patchy-zoned and inclusion-rich zircon (such as those shown in Fig. 6e) resulted in irregular trace-element distribution throughout the analyses. For comparison, two of these analyses are plotted in Figs. 7, 8 (A71 inclusion-rich) and show systematically high $\mathrm{Y}, \mathrm{Sr}, \mathrm{Ca}, \mathrm{Yb}$, and $\mathrm{P}$ contents. On the other hand, zircons from sample A91, which display welldeveloped growth zoning and are generally free of fractures and inclusions, have a more homogeneous trace element composition. This suggests that their composition is effectively reflecting crystallization from the melt and is not contaminated by micro-inclusions.

The chemical composition of the zircons follows the differentiation trend defined by bulk rock composition (A91-A71). There is a slight increase of incompatible elements in zircon from sample A91 and L165 to A71 $\left(\Sigma_{(\mathrm{Sm}-\mathrm{Lu})}\right)=869,1075$ and 2490 , respectively $)$. The chondrite-normalized REE pattern of zircons from the three samples (Fig. 8) is enriched in heavy-REE with respect to the light-REE, as typical for magmatic zircon (Hinton and Upton 1991). Despite the variation within a single sample, HREE enrichment in zircon is broadly decreasing with differentiation (i.e. from sample A91 to 
Table 1 SHRIMP analyses of zircons

\begin{tabular}{|c|c|c|c|c|c|c|c|c|c|c|}
\hline Grain spot & $\begin{array}{l}\mathrm{U} \\
(\mathrm{ppm})\end{array}$ & $\begin{array}{l}\text { Th } \\
(\mathrm{ppm})\end{array}$ & $\mathrm{Th} / \mathrm{U}$ & $\begin{array}{l}\mathrm{Pb}^{\mathrm{a}} \\
(\mathrm{ppm})\end{array}$ & $\begin{array}{l}\mathrm{Pb} \text { comm } \\
206 \%\end{array}$ & $\begin{array}{l}\text { Uncorrected } \\
207 \mathrm{~Pb} / 206 \mathrm{~Pb}\end{array}$ & $\begin{array}{l}\text { Uncorrected } \\
238 \mathrm{U} / 206 \mathrm{~Pb}\end{array}$ & $206 \mathrm{~Pb} / 238 \mathrm{U} \pm(1)$ & $\begin{array}{l}\text { ages }(\mathrm{Ma}) 206 \mathrm{~Pb} / \\
238 \mathrm{U} 208 \text { cor }\end{array}$ & CL structure \\
\hline L165B.1.1 & 84 & 47 & 0.55 & 1.9 & 0.52 & $0.055 \pm 2$ & $39.0 \pm 0.8$ & $0.0256 \pm 5$ & $162 \pm 3$ & zoned \\
\hline L165B.2.1 & 310 & 137 & 0.44 & 6.7 & 0.41 & $0.052 \pm 1$ & $40.0 \pm 0.6$ & $0.0250 \pm 4$ & $159 \pm 3$ & patchy \\
\hline L165B.3.1 & 33 & 12 & 0.38 & 0.7 & 2.02 & $0.066 \pm 9$ & $41.2 \pm 1.1$ & $0.0243 \pm 6$ & $152 \pm 4$ & unzoned \\
\hline L165B.3.2 & 19 & 9 & 0.50 & 0.4 & 2.76 & $0.063 \pm 6$ & $39.9 \pm 1.3$ & $0.0251 \pm 8$ & $155 \pm 6$ & unzoned \\
\hline L165B.4.1 & 385 & 132 & 0.34 & 8.4 & 0.26 & $0.054 \pm 1$ & $39.3 \pm 0.6$ & $0.0255 \pm 4$ & $162 \pm 3$ & new zoning \\
\hline L165B.4.2 & 199 & 113 & 0.57 & 4.2 & 0.12 & $0.050 \pm 2$ & $41.0 \pm 0.8$ & $0.0244 \pm 5$ & $155 \pm 3$ & new zoning \\
\hline L165B.4.3 & 240 & 94 & 0.39 & 5.3 & 0.16 & $0.050 \pm 1$ & $38.5 \pm 0.6$ & $0.0260 \pm 4$ & $165 \pm 3$ & unzoned \\
\hline L165B.4.4 & 228 & 103 & 0.45 & 5.0 & 0.29 & $0.054 \pm 1$ & $39.3 \pm 0.6$ & $0.0254 \pm 4$ & $161 \pm 3$ & patchy \\
\hline L165B.5.1 & 39 & 21 & 0.55 & 0.8 & 1.56 & $0.059 \pm 4$ & $39.8 \pm 1.0$ & $0.0251 \pm 6$ & $157 \pm 4$ & unzoned \\
\hline L165B.6.1 & 776 & 442 & 0.57 & 17.4 & $<0.01$ & $0.050 \pm 1$ & $38.3 \pm 0.6$ & $0.0261 \pm 4$ & $167 \pm 3$ & patchy \\
\hline L165B.6.2 & 622 & 326 & 0.52 & 14.0 & 0.01 & $0.051 \pm 1$ & $38.1 \pm 0.6$ & $0.0263 \pm 4$ & $167 \pm 4$ & patchy \\
\hline L165B.7.1 & 157 & 58 & 0.37 & 3.5 & 0.25 & $0.053 \pm 2$ & $38.9 \pm 0.7$ & $0.0257 \pm 4$ & $163 \pm 3$ & unzoned \\
\hline L165B.7.2 & 194 & 78 & 0.40 & 4.2 & $<0.01$ & $0.051 \pm 2$ & $39.4 \pm 0.6$ & $0.0254 \pm 4$ & $162 \pm 4$ & on fracture \\
\hline L165B.8.1 & 162 & 527 & 3.25 & 3.2 & $<0.01$ & $0.055 \pm 2$ & $43.2 \pm 0.7$ & $0.0232 \pm 4$ & $151 \pm 6$ & patchy \\
\hline L165B.10.1 & 16 & 10 & 0.59 & 0.3 & 0.10 & $0.050 \pm 6$ & $41.0 \pm 1.4$ & $0.0244 \pm 8$ & $155 \pm 6$ & patchy \\
\hline A71.1.1 & 499 & 394 & 0.79 & 11.2 & $<0.01$ & $0.051 \pm 1$ & $38.5 \pm 0.6$ & $0.0260 \pm 4$ & $166 \pm 3$ & patchy \\
\hline A71.2.1 & 436 & 881 & 2.02 & 9.5 & $<0.01$ & $0.051 \pm 1$ & $39.2 \pm 0.7$ & $0.0255 \pm 4$ & $166 \pm 4$ & unzoned \\
\hline A71.3.1 & 61 & 28 & 0.47 & 1.4 & 4.01 & $0.074 \pm 3$ & $38.6 \pm 0.8$ & $0.0256 \pm 5$ & $158 \pm 4$ & unzoned \\
\hline A71.5.1 & 92 & 185 & 2.01 & 2.0 & 2.36 & $0.060 \pm 3$ & $40.0 \pm 0.8$ & $0.0250 \pm 5$ & $155 \pm 5$ & patchy \\
\hline A71-6.1 & 111 & 40 & 0.36 & 2.5 & 1.86 & $0.053 \pm 2$ & $38.1 \pm 0.6$ & $0.0263 \pm 4$ & $166 \pm 3$ & unzoned \\
\hline A71-7.1 & 109 & 139 & 1.27 & 2.4 & 0.98 & $0.051 \pm 2$ & $38.9 \pm 0.6$ & $0.0257 \pm 4$ & $163 \pm 3$ & patchy \\
\hline A71-8.1 & 174 & 94 & 0.54 & 3.9 & 0.00 & $0.051 \pm 3$ & $38.3 \pm 0.6$ & $0.0261 \pm 4$ & $166 \pm 3$ & patchy \\
\hline A71-9.1 & 85 & 45 & 0.53 & 1.9 & 6.48 & $0.053 \pm 2$ & $39.2 \pm 0.9$ & $0.0255 \pm 6$ & $162 \pm 4$ & unzoned \\
\hline A71-10.1 & 760 & 1051 & 1.38 & 16.9 & 0.49 & $0.051 \pm 1$ & $38.7 \pm 0.5$ & $0.0258 \pm 3$ & $164 \pm 3$ & growth \\
\hline A71-11.1 & 121 & 140 & 1.16 & 2.6 & 4.96 & $0.059 \pm 2$ & $39.5 \pm 0.6$ & $0.0253 \pm 4$ & $161 \pm 3$ & patchy \\
\hline A71-12.1 & 39 & 23 & 0.59 & 0.9 & 16.80 & $0.074 \pm 4$ & $38.5 \pm 0.8$ & $0.0260 \pm 5$ & $163 \pm 4$ & unzoned \\
\hline A71-13.1 & 28 & 11 & 0.38 & 0.6 & 22.69 & $0.074 \pm 5$ & $38.1 \pm 0.9$ & $0.0262 \pm 6$ & $163 \pm 4$ & patchy \\
\hline A71-14.1 & 37 & 13 & 0.35 & 0.8 & 21.05 & $0.077 \pm 8$ & $38.1 \pm 0.8$ & $0.0262 \pm 6$ & $164 \pm 4$ & growth \\
\hline A71-15.1 & 206 & 630 & 3.06 & 4.5 & 3.73 & $0.055 \pm 2$ & $39.7 \pm 0.6$ & $0.0252 \pm 4$ & $162 \pm 5$ & patchy \\
\hline A71-16.1 & 57 & 55 & 0.97 & 1.3 & 11.20 & $0.065 \pm 3$ & $37.2 \pm 0.7$ & $0.0269 \pm 5$ & $166 \pm 4$ & growth \\
\hline A71-17.1 & 273 & 268 & 0.98 & 5.7 & 1.95 & $0.051 \pm 1$ & $40.9 \pm 0.6$ & $0.0244 \pm 3$ & $155 \pm 3$ & patchy \\
\hline A71-18.1 & 30 & 19 & 0.61 & 0.6 & 20.14 & $0.078 \pm 5$ & $41.8 \pm 1.0$ & $0.0239 \pm 6$ & $149 \pm 4$ & patchy \\
\hline A91-1.1 & 36 & 33 & 0.91 & 0.7 & $<0.01$ & $0.051 \pm 4$ & $42.8 \pm 1.1$ & $0.0234 \pm 6$ & $151 \pm 5$ & rim \\
\hline A91-1.2 & 469 & 1480 & 3.15 & 9.9 & $<0.01$ & $0.049 \pm 1$ & $40.9 \pm 0.6$ & $0.0245 \pm 4$ & $158 \pm 5$ & growth \\
\hline A91-1.3 & 30 & 66 & 2.21 & 0.6 & 8.63 & $0.074 \pm 8$ & $41.9 \pm 1.1$ & $0.0239 \pm 7$ & $159 \pm 7$ & rim \\
\hline A91.1.4 & 13 & 35 & 2.63 & 0.2 & 15.54 & $0.081 \pm 9$ & $46.7 \pm 2.9$ & $0.0214 \pm 13$ & $136 \pm 16$ & rim \\
\hline A91.2.1 & 5 & 4 & 0.81 & 0.1 & 30.25 & $0.113 \pm 17$ & $39.8 \pm 2.3$ & $0.0251 \pm 15$ & $150 \pm 11$ & patchy \\
\hline A91.2.2 & 5 & 4 & 0.75 & 0.1 & 6.82 & $0.082 \pm 17$ & $38.0 \pm 2.2$ & $0.0263 \pm 15$ & $156 \pm 12$ & unzoned \\
\hline A91-3.1 & 68 & 58 & 0.85 & 1.5 & 13.73 & $0.070 \pm 4$ & $39.8 \pm 0.7$ & $0.0251 \pm 5$ & $159 \pm 3$ & patchy \\
\hline A91-4.1 & 123 & 87 & 0.71 & 2.7 & 1.36 & $0.059 \pm 2$ & $39.3 \pm 0.7$ & $0.0255 \pm 4$ & $162 \pm 3$ & patchy \\
\hline A91-4.2 & 62 & 58 & 0.93 & 1.4 & 6.02 & $0.062 \pm 5$ & $39.4 \pm 0.7$ & $0.0254 \pm 5$ & $161 \pm 4$ & patchy \\
\hline A91-5.1 & 22 & 42 & 1.93 & 0.5 & 23.09 & $0.084 \pm 8$ & $36.8 \pm 1.0$ & $0.0227 \pm 7$ & $172 \pm 7$ & unzoned \\
\hline A91-6.1 & 31 & 1 & 0.04 & 0.7 & 12.09 & $0.081 \pm 7$ & $37.2 \pm 0.8$ & $0.0269 \pm 16$ & $167 \pm 4$ & patchy \\
\hline A91-7.1 & 259 & 398 & 1.54 & 5.2 & 4.82 & $0.055 \pm 1$ & $42.5 \pm 0.6$ & $0.0235 \pm 3$ & $151 \pm 3$ & patchy \\
\hline A91-8.1 & 29 & 46 & 1.59 & 0.6 & 22.39 & $0.088 \pm 5$ & $38.7 \pm 0.9$ & $0.0258 \pm 6$ & $163 \pm 6$ & unzoned \\
\hline A91-9.1 & 48 & 32 & 0.67 & 1.0 & 5.65 & $0.067 \pm 3$ & $40.8 \pm 0.8$ & $0.0245 \pm 5$ & $156 \pm 4$ & patchy \\
\hline A91-11.1 & 244 & 176 & 0.72 & 5.2 & 4.65 & $0.055 \pm 1$ & $40.1 \pm 0.6$ & $0.0250 \pm 3$ & $158 \pm 2$ & patchy \\
\hline A91-12.1 & 212 & 372 & 1.76 & 4.5 & 1.88 & $0.054 \pm 1$ & $40.8 \pm 0.6$ & $0.0245 \pm 3$ & $158 \pm 3$ & growth \\
\hline
\end{tabular}


Table 1 continued

\begin{tabular}{|c|c|c|c|c|c|c|c|c|c|c|}
\hline Grain spot & $\begin{array}{l}\mathrm{U} \\
(\mathrm{ppm})\end{array}$ & $\begin{array}{l}\text { Th } \\
(\mathrm{ppm})\end{array}$ & $\mathrm{Th} / \mathrm{U}$ & $\begin{array}{l}\mathrm{Pb}^{\mathrm{a}} \\
(\mathrm{ppm})\end{array}$ & $\begin{array}{l}\mathrm{Pb} \text { comm } \\
206 \%\end{array}$ & $\begin{array}{l}\text { Uncorrected } \\
207 \mathrm{~Pb} / 206 \mathrm{~Pb}\end{array}$ & $\begin{array}{l}\text { Uncorrected } \\
238 \mathrm{U} / 206 \mathrm{~Pb}\end{array}$ & $206 \mathrm{~Pb} / 238 \mathrm{U} \pm(1)$ & $\begin{array}{l}\text { ages }(\mathrm{Ma}) 206 \mathrm{~Pb} / \\
238 \mathrm{U} 208 \text { cor }\end{array}$ & CL structure \\
\hline A91-13.1 & 200 & 131 & 0.66 & 4.3 & 5.42 & $0.059 \pm 2$ & $39.4 \pm 0.6$ & $0.0254 \pm 4$ & $161 \pm 3$ & patchy \\
\hline A91-14.1 & 24 & 18 & 0.74 & 0.5 & 44.74 & $0.097 \pm 6$ & $37.4 \pm 1.0$ & $0.0627 \pm 7$ & $165 \pm 5$ & patchy \\
\hline A91-15.1 & 47 & 21 & 0.45 & 1.0 & 23.85 & $0.074 \pm 4$ & $38.3 \pm 0.8$ & $0.0261 \pm 6$ & $164 \pm 4$ & unzoned \\
\hline A91-16.1 & 42 & 43 & 1.02 & 0.9 & 22.69 & $0.085 \pm 5$ & $39.2 \pm 0.8$ & $0.0255 \pm 5$ & $160 \pm 4$ & patchy \\
\hline A91-17.1 & 42 & 46 & 1.09 & 0.9 & 13.30 & $0.081 \pm 5$ & $38.9 \pm 0.8$ & $0.0257 \pm 5$ & $162 \pm 4$ & patchy \\
\hline A91-18.1 & 40 & 42 & 1.03 & 0.9 & 20.22 & $0.090 \pm 4$ & $36.8 \pm 0.8$ & $0.0272 \pm 6$ & $173 \pm 5$ & unzoned \\
\hline A91-19.1 & 82 & 70 & 0.85 & 1.7 & 13.00 & $0.080 \pm 3$ & $40.5 \pm 0.7$ & $0.0247 \pm 4$ & $155 \pm 3$ & patchy \\
\hline A91-20.1 & 33 & 15 & 0.45 & 0.7 & 25.41 & $0.092 \pm 5$ & $39.6 \pm 0.9$ & $0.0252 \pm 6$ & $159 \pm 4$ & unzoned \\
\hline V16-1 & 17 & 10 & 0.45 & 0.4 & 0.40 & $0.053 \pm 5$ & $37.9 \pm 1.7$ & $0.0264 \pm 12$ & $167 \pm 8$ & growth \\
\hline V16-1A & 59 & 73 & 1.24 & 1.3 & 0.06 & $0.050 \pm 3$ & $39.7 \pm 0.7$ & $0.0252 \pm 5$ & $158 \pm 4$ & growth \\
\hline V16-2 & 31 & 13 & 0.41 & 0.7 & $<0.01$ & $0.049 \pm 4$ & $39.4 \pm 1.0$ & $0.0254 \pm 6$ & $161 \pm 4$ & growth \\
\hline
\end{tabular}

a radiogenic lead

L165 and A71), whereas the negative Eu anomaly increases (eTable 3 and Fig. 7) and correlates with Y contents (Fig. 8a). The Eu anomaly suggests plagioclase fractionation in the magma and is in line with a magmatic origin of the zircon. Two analyses in sample L165 have a slight positive Eu anomaly, which is attributed to micro inclusions of plagioclase. Because most trace elements are orders of magnitude lower in plagioclase than in zircon (except $\mathrm{Sr}$ and LREE) these analyses are still considered valid for all other elements. All zircon also have a positive $\mathrm{Ce}$ anomaly (Fig. 7) originated from the $\mathrm{Ce}^{3+}$ oxidized to $\mathrm{Ce}^{4+}$, which better fits the $\mathrm{Zr}$ site in zircon (Hinton and Upton 1991).

\section{U-Pb geochronology}

$\mathrm{U}-\mathrm{Pb}$ ages were obtained from three samples (L165, A91 and A71) for which the ${ }^{206} \mathrm{~Pb} /{ }^{238} \mathrm{U}$ ages are discussed below (Table 1). Zircons analyses from L165 ( $n=15$ from nine crystals) have a $\mathrm{Th} / \mathrm{U}$ mainly between 0.34 and 0.65 with the exception of one analysis with a ratio of 3.25 due to very high Th contents. In this sample there is no apparent correlation between age and internal structure, with CL-dark zones along fractures yielding the same age as pristine magmatic zones (Fig. 6). The ${ }^{206} \mathrm{~Pb} /{ }^{238} \mathrm{U}$ ages range from $151 \pm 6$ to $167 \pm 4$ Ma. Two analyses (L1659.1 and L165-11.1) that contain a high percent of common $\mathrm{Pb}(12$ and 39\%) and large analytical errors were excluded from the age calculation. Of the remaining analyses, 13 form a tight cluster with an intercept age of $162 \pm 2 \mathrm{Ma}$ (MSWD = 1.6, Fig. 9a). Two analyses, including the one with high $\mathrm{Th}$, yielded significantly younger ages and are suspected of $\mathrm{Pb}$ loss. The intense fracturing of zircons and Alpine metamorphism could be the likely cause of $\mathrm{Pb}$ loss.
At these young ages, even discordant analyses are close to Concordia and discordance cannot be necessarily identified with the present analytical errors. Therefore, analyses affected by $\mathrm{Pb}$ loss might still be analytically concordant, but their exclusion from average age calculations is justified on statistical and geological reasons.

A large number of analyses $(n=24)$ were performed on zircon from metagabbro A91 because of the complex texture observed. The chemistry of the dated domains is quite variable with $\mathrm{U}$ between 5 and $469 \mathrm{ppm}$, Th between 4 and $1,480 \mathrm{ppm}$ and $\mathrm{Th} / \mathrm{U}$ from 0.04 to 3.15 . The ${ }^{206} \mathrm{~Pb} /{ }^{238} \mathrm{U}$ ages range between $136 \pm 16$ and $173 \pm 5 \mathrm{Ma}$, with large analytical errors and high common $\mathrm{Pb}$ (up to $44 \%$ ) in domains with low $\mathrm{U}$ contents. Four analyses on unzoned rims (Fig. 6f) or bright domains yielded significantly younger ages and are excluded from the age calculation. The remaining analyses correspond to oscillatory-zoned domains as well as to unzoned or bright domains and define a regression line to common $\mathrm{Pb}$ with a lower intercept of $158 \pm 2 \mathrm{Ma}$ $(\mathrm{MSWD}=1.7$, Fig. 9b).

Seventeen analyses on zircon from $\mathrm{Fe}$-gabbro A71 yielded variable $\mathrm{U}$ and Th composition (28-760 and 11$1051 \mathrm{ppm}$, respectively) with resulting $\mathrm{Th} / \mathrm{U}$ between 0.4 and 3.2. Fifteen analyses range in age from $155 \pm 2$ to $166 \pm 4 \mathrm{Ma}$ and define an intercept age of $163 \pm 1 \mathrm{Ma}$ $($ MSWD $=1.2)$. Two analyses resulting in significantly younger ages are excluded from the age calculation.

A small number of analyses $(n=3)$ were performed on zircons from the plagiogranite $\mathrm{V} 16 .{ }^{206} \mathrm{~Pb} /{ }^{238} \mathrm{U}$ ages of these oscillatory zones domains are between $161 \pm 4$ and $167 \pm 8 \mathrm{Ma}$ (Table 1). These data are insufficient to define a robust regression in a Tera-Wasserburg diagram, but are sufficient to suggest that this rock type is within the same range of the $\mathrm{Fe}$-gabbros. 

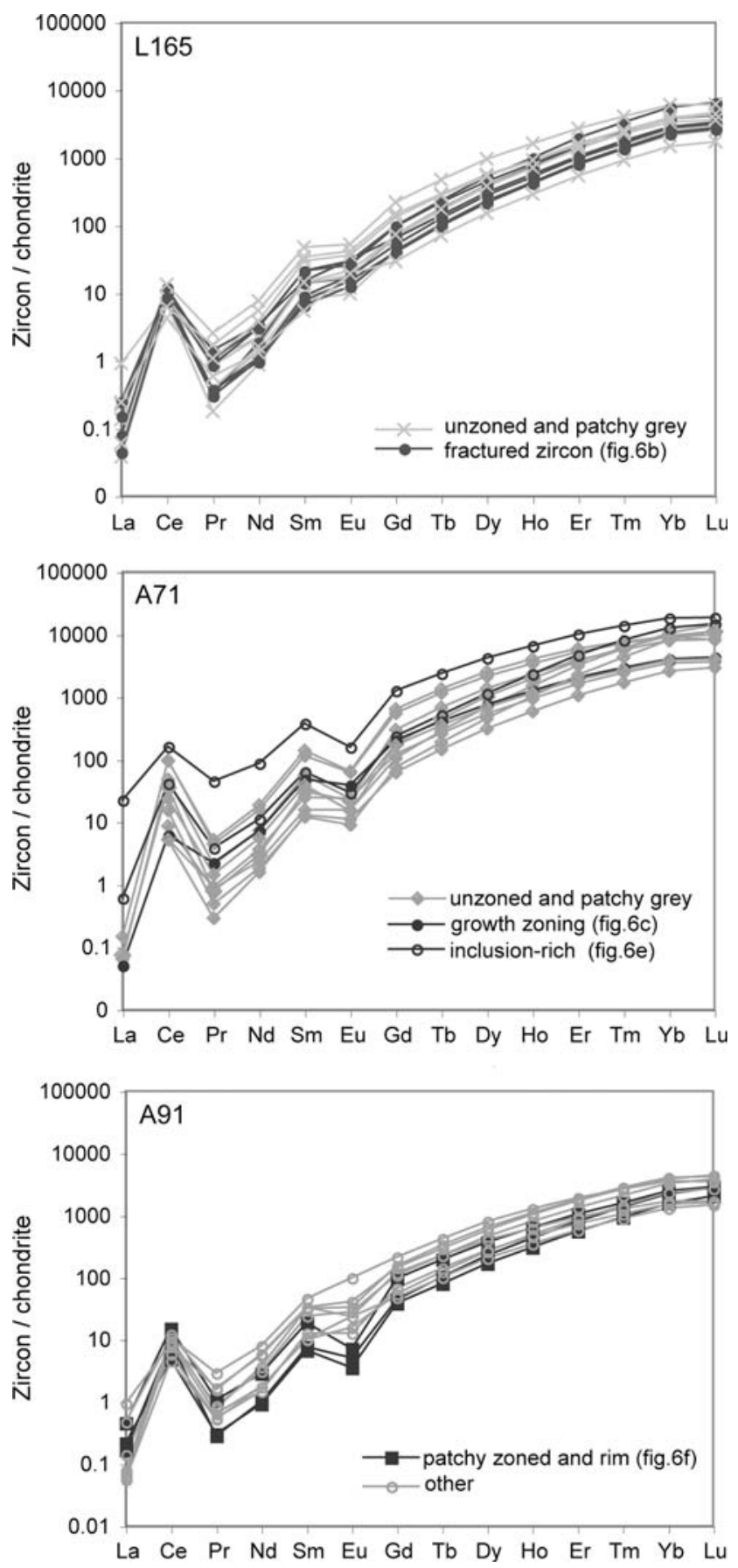

Fig. 7 Chondrite normalized REE diagrams of zircons from $\mathrm{Fe}-$ gabbros L165, A 91, and A 71. Normalization values for chondrite are taken from Sun and McDonough (1989)

\section{Discussion}

Chemical differentiation of mafic rocks

The Lanzo mafic rocks show a tholeiitic differentiation trend, covering the entire range of gabbroic rocks, from primitive plagioclase-rich troctolite and olivine-gabbros, to
Fe-Ti gabbros and plagiogranite (Pognante et al. 1985). This range is typical for some other ophiolites from the western, eastern Alps and northern Apennine (Costa and Caby 2001; Desmurs et al. 2002; Serri 1980; Tribuzio et al. 2004).

The large variation of Mg\# (Fig. 4) indicates that most dikes record differentiation processes and only a few samples provide evidence of being crystallized from primitive liquids. The high $\mathrm{Mg} \#$ (up to 0.9) and high $\mathrm{Al}_{2} \mathrm{O}_{3}$ contents in olivine-gabbros and troctolites are consistent with being cumulates crystallized from primitive basalts with $\mathrm{Mg} \# \sim 0.7$, taking olivine-liquid partition coefficients of $\sim 0.3$ (Roeder and Emslie 1970). However, basalts with $\mathrm{Mg \#}$ of $\sim 0.7$ are extremely rare (Fig. 4) and the average $\mathrm{Mg \#}$ of basalts recovered from various fragments of the Tethyan oceanic crust is around 0.6 (Fig. 4). Thus, there must be an important volume of plutonic rocks in the mantle to account for the differentiated composition of most basalt. The high Mg\# troctolites and olivine-gabbros are low in incompatible trace elements like $\mathrm{Ti}, \mathrm{Zr}$ and $\mathrm{P}$ and would thus fulfill the criteria of being the complementary cumulates of evolved basalts.

The three zircon-bearing ferro-gabbros have substantially higher $\mathrm{Zr}$ compared to average $\mathrm{Fe}-\mathrm{Ti}$ gabbros. The high $\mathrm{Zr}$ contents could be partly explained by migration of highly differentiated melts along shear zones from a cumulate pile beneath the actual level of crystallization.

The Eu anomaly in zircon-bearing Fe-Ti gabbros varies from positive to negative suggesting that these gabbros had a different genesis. The threefold increase of whole rock REE element enrichment is related to differentiation. However, the Eu concentrations remain almost constant (Fig. 5) and Eu anomalies change from being positive to negative. This suggests that the different zircon-bearing samples record different fractionation processes. While a positive Eu anomaly is indicative of plagioclase accumulation, the negative Eu anomaly of some samples indicates substantial plagioclase fractionation prior to the solidification of the gabbro. Surprisingly, the chemical features can be linked with the texture of individual gabbro samples. Zircon-bearing gabbroic dikes with a granular texture (A71) have a positive Eu anomalies indicate in situ crystallization, with large amounts of trapped liquid, from which zircon (and other trace phases) crystallized in situ. On the contrary, sample A91, which is highly sheared, has a negative Eu anomaly, indicating that substantial amounts of plagioclase fractionation occurred at depth, prior to the solidification of the gabbro. Zircons are concentrated in the middle of a highly sheared zone, suggesting that differentiated liquid moved from below, along shear zones. Gabbro L165, which has a central shear zone present an intermediate composition between the other two samples (A91 and A71). Assuming that the all $\mathrm{Fe}-\mathrm{Ti}$ gabbros might be 
Fig. 8 Zircon trace element composition measured by LAICP-MS. a $\mathrm{Eu} / \mathrm{Eu}^{*}$ vs $\mathrm{Y}$. Zircons from A71 have substantially more negative Eu anomalies and tend to much higher Y contents with respect to the other samples. b Th vs U. Zircons from different samples show two different $\mathrm{Th} / \mathrm{U}$ ratio trends, which are probably controlled by coexisting silicate liquids. c Sr vs $\mathrm{Yb}$. d U vs $\mathrm{P}$.

Some analyses show

$\mathrm{Sr}>10 \mathrm{ppm}$ and

$P>2000$ ppm, which might be related to apatite microinclusions. See text for further discussion
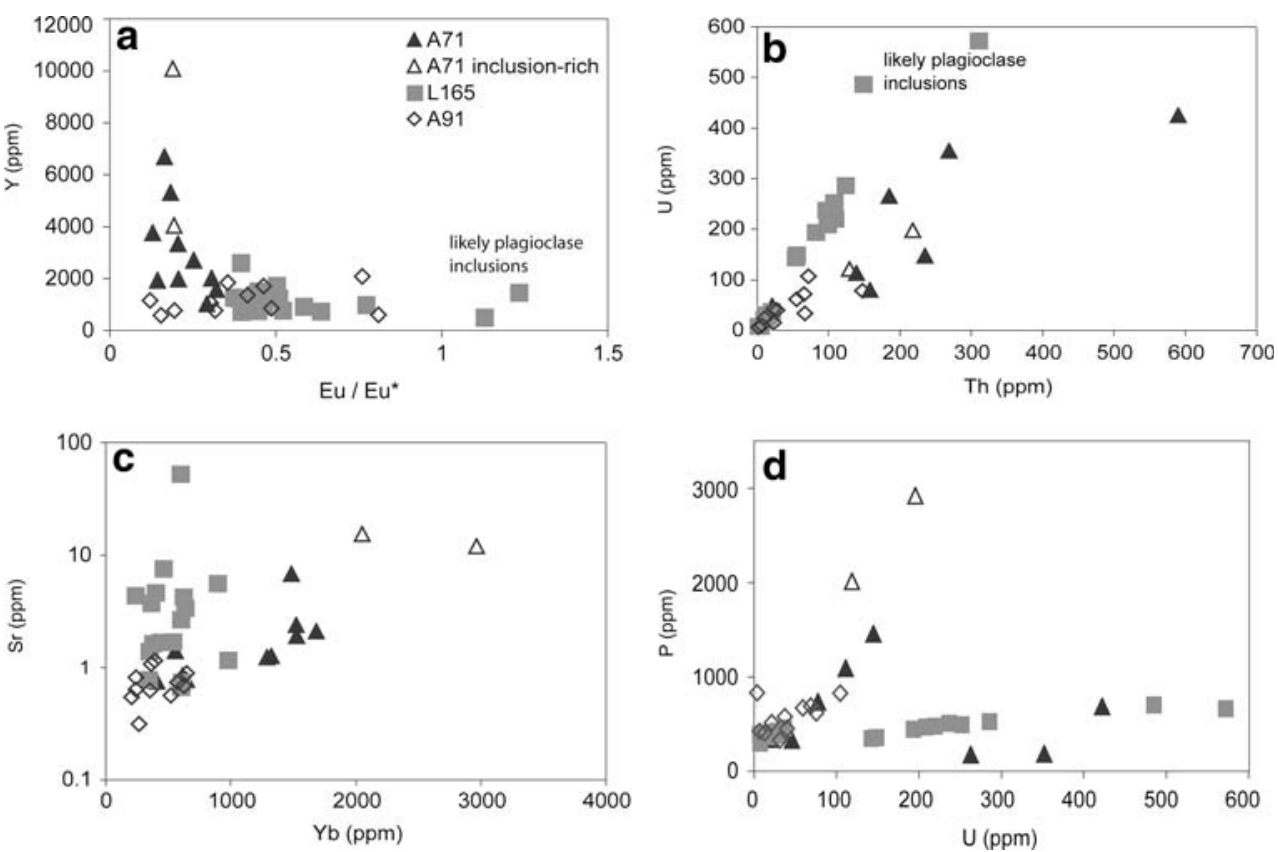

originated from a similar source, we propose that their chemical and textural differences most probably reflect different emplacement mechanisms, which evolved through time.

In contrast to most other gabbros, the plagiogranite shows a large negative Eu anomaly $\left(\mathrm{Eu}^{*} \sim 0.30\right)$ suggesting substantial plagioclase fractionation prior to dike formation. This is consistent with crystal fractionation modeling for the genesis of plagiogranites (Aldiss 1981).

Age interpretation and zircon chemistry

The zircon dated present features indicative of a magmatic origin. They occasionally preserve euhedral crystal faces, display weak oscillatory zoning or are unzoned. They have high $\mathrm{Th} / \mathrm{U}$ as often observed in magmatic zircon from mafic rock types (Corfu et al. 2003; Rubatto and Gebauer 2000). The steep REE pattern and the negative Euanomaly are in line with crystallization from a melt after substantial plagioclase fractionation. Therefore the $\mathrm{U}-\mathrm{Pb}$ ages obtained are interpreted as crystallization ages at around $\sim 160 \mathrm{Ma}$.

The application of the Ti-in-zircon thermometer (Watson et al. 2006) to the investigated samples returns temperatures of $775 \pm 15^{\circ} \mathrm{C}$ for L165, $751 \pm 61^{\circ} \mathrm{C}$ for A71 and $822 \pm 37^{\circ} \mathrm{C}$ for $\mathrm{A} 91$ (eTable 3). Assuming a $\mathrm{TiO}_{2}$ activity of 0.5 , as likely for these ilmenite-bearing gabbros, would increase the estimated temperature by $\sim 50^{\circ} \mathrm{C}$ (Watson and Harrison 2005). Even with this correction, the temperatures obtained from zircon are much lower than what expected for the crystallization of ferro-gabbros and the variations within a single sample are large. This has been documented elsewhere and attributed to the fact that zircon is a late crystallizing phase and its Ti-content might represent local melt composition, rather than the original chemistry of the mafic magma (Coogan and Hinton 2006; Hiess et al. 2006).

Of particular interest is the network of apparent fractures observed in many crystals (Fig. 6). Similar features in zircon grains from mafic rocks have been recently studied in detail with electron back scattered diffraction (EBSD) techniques (Reddy et al. 2006; Timms et al. 2006). Their results show that these networks of apparent fractures correspond to dislocation structures, rather than open and resealed fractures. Timms et al. (2006) documented that deformed zones defining sub-grains correspond to zones of CL intensity decrease due to either structural or chemical changes during deformation. In the Lanzo samples, the zircon within the shear zones show the highest concentration of these apparent fractures, indicating that they are possibly related to dislocation zones. These dislocations have the same age within error and slightly lower REE concentrations when compared to pristine oscillatory zones (see in particular sample L165). This would suggest that, even though there was some chemical and possibly isotopic changes in the deformed zones, shearing must have occurred simultaneous to, or shortly after crystallization of the zircon, producing an irrelevant loss of radiogenic $\mathrm{Pb}$. Strong syn-magmatic deformation is in fact reflected in the structure of the high-temperature shear zones. The dated samples later underwent variable degrees of HP metamorphic overprint during the Alpine orogeny; therefore it is not surprising that a few analyses, particularly on 

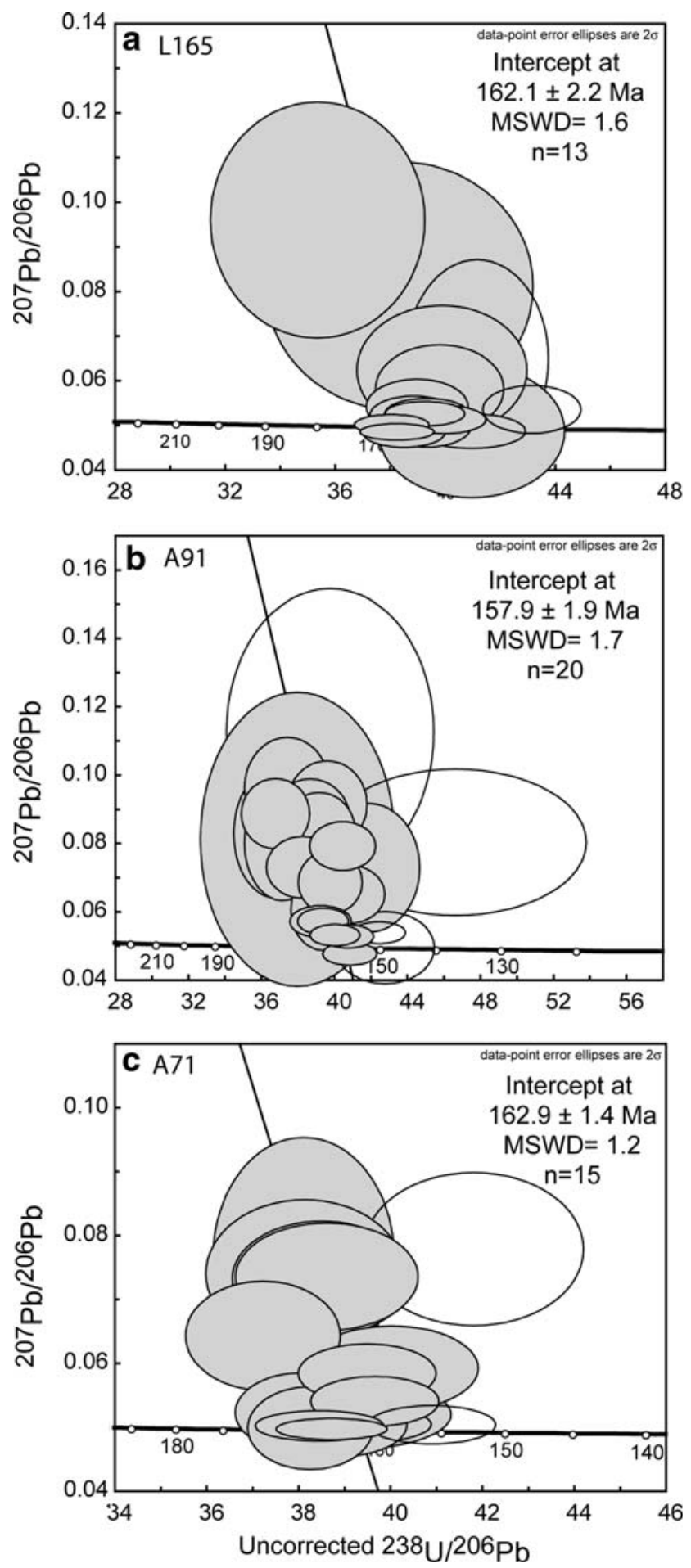

Fig. 9 Tera-Wasserburg diagram for uncorrected isotopic ratios for zircons of samples L165, A71 and A91. Ages are calculated as Concordia intercept at $95 \% \mathrm{Cl}$ of a regression line anchored to the common $\mathrm{Pb}$ composition predicted by the Stacey and Kramers (1975) model. Empty ellipses are excluded from the average age calculation

unzoned zircon rims (sample A91) yielded substantially younger ages, which are attributed to Pb-loss during Cenozoic metamorphism.
In summary, $\mathrm{U}-\mathrm{Pb}$ dating constrain the intrusion of the gabbros at $161 \pm 2,158 \pm 2$ and $163 \pm 1$ Ma. The small age difference between the youngest and the oldest gabbro $(5 \pm 1.1 \mathrm{Ma}, 1$ sigma) suggests magmatism over a few millions of years, which is possibly linked to the chemical evolution of the magmatic system that ultimately formed the gabbro dikes. The youngest intrusion age (158 $\pm 2 \mathrm{Ma})$ corresponds to the most deformed dike (A91), which is also the most fractionated sample, with evidence of plagioclase fractionation prior to crystallization. The sample L165 shows an intermediate composition in terms of REE. The undeformed gabbro A71 crystallized at $163 \pm 1 \mathrm{Ma}$ and its chemistry suggests plagioclase accumulation, reflected by a positive whole rock Eu anomaly (Fig. 5a). We therefore suggest that zircon formation in this sample is related to in situ crystallization of trapped interstitial liquid. The correlation between structure, geochemistry and age suggests the following scenario: (1) emplacement of gabbros and in-situ crystallization, followed by (2) crystallization of zircon-bearing oxide gabbros along syn-magmatic shear zones. This latter, fractionated magma was extracted from cumulate gabbros at depth. Such a scenario implies that the formation of a "stratified" oceanic crust might be time progressive, with "early magmatism" dominated by in situ crystallization of individual magma batches and "later magmatism" accompanied by syn-magmatic deformation, enhancing efficient extraction of highly differentiated liquid from a cumulus pile.

Tracking the thermal evolution of a nascent ultra-slow spreading system

The Lanzo massif was partly re-equilibrated during uplift from the spinel to the plagioclase facies (Kaczmarek and Müntener 2007; Sandrone et al. 1986), which was accompanied by cooling from $>1,100^{\circ} \mathrm{C}$ to $850^{\circ} \mathrm{C}$ (Kaczmarek and Müntener 2007; Pognante et al. 1985) and by fracturing and intrusion of gabbroic dikes generated at greater depth. The gabbro dikes studied here indicate intrusions in a refertilized, brittle mantle along fractures. It is likely that magmatism composed of several pulses from a source close to N-MORB persisted for some millions of years.

Published radiometric ages suggest that mafic magmatism in the Piemont-Ligurian ophiolites lasted from $\sim 170$ to $150 \mathrm{Ma}$ with different types of gabbroic rocks intruding is sequence. Gabbros from the Ligurian peridotite were dated by $\mathrm{Sm}-\mathrm{Nd}$ mineral isochrons (plagioclase-clinopyroxene) and represent the earliest group of MORB-type gabbros (external Liguride gabbros: $179 \pm 9$ and Tuscany gabbros: $170 \pm 13$ and $173 \pm 4.8 \mathrm{Ma}$ ), (Tribuzio et al. 2004). These gabbros are interpreted as representing early 
(syn-rift) melt intrusion in lithospheric mantle peridotite. $\mathrm{U}-\mathrm{Pb}$ zircon ages on zircon-bearing $\mathrm{Fe}-\mathrm{Ti}$ gabbros from the Piemont-Ligurian ocean show ages ranging between 166 and $156 \mathrm{Ma}$ (Costa and Caby 2001; Ohnenstetter et al. 1981; Rubatto et al. 1998; Rubatto and Hermann 2003; Schaltegger et al. 2002) consistent with the new age determinations from Lanzo gabbros. Similar ages were obtained for Internal Liguride gabbros with $\mathrm{Sm}-\mathrm{Nd}$ mineral isochrons at $164 \pm 14 \mathrm{Ma}$, (Rampone et al. 1998).

Plagiogranites from a number of localities in the western Alps and the Apennine were found to be significantly younger than the corresponding mafic rocks: $150-153 \mathrm{Ma}$ (Borsi et al. 1996), $148 \pm 2$ Ma (Costa and Caby 2001), $152 \pm 2 \mathrm{Ma}$ (Lombardo et al. 2002). The plagiogranites described by Costa and Caby (2001) cut across breccias and basaltic rocks and thus clearly postdate continental breakup. On the other hand, plagiogranites from the Platta nappe and those described in this paper show similar age as the zircon bearing gabbros. We conclude that the $\sim 160 \mathrm{Ma}$ plagiogranites are formed by differentiation whereas the younger ones are eventually formed by different processes, possibly hydrous melting (Koepke et al. 2005).

\section{Paleogeographic consequences}

The intrusion of mafic melts recorded in Piemont-Ligurian ophiolites of the western Alps, Corsica and northern Apennines lasted from 180 to $150 \mathrm{Ma}$ with most gabbros intruding at 165-160 Ma. The spatial distribution of ages illustrated on Fig. 10 indicates a progressive younging of the first crystallization ages from the south (Tuscany and northern Apennines) to the north (Platta nappe) of the Piemont-Ligurian ocean. However, the different gabbroic rocks, albeit crystallized from MORB type melts, are found in different structural/paleogeographic domains. For example the Monviso gabbros are intruded in a "mature" oceanic crust, related to important volumes of basaltic rocks, while the gabbros from the Nappe des Gets and the Platta gabbros are intruded into the ocean-continent transition zone. There is an age difference of $\sim 5 \pm 2 \mathrm{my}$ between the intrusion of the gabbros in the Gets nappe (166 \pm 1 Ma, Bill et al. 1997) and those in the Platta nappe $(161 \pm 1 \mathrm{Ma}$, Schaltegger et al. 2002). Gabbros in both localities intruded into an ocean-continent transition zone, separated by approximately $250 \pm 100 \mathrm{~km}$, by taking the paleogeographic reconstructions of Froitzheim et al. (1996). Assuming that the opening mechanism remains similar for both localities, an average rate of $5 \mathrm{~cm} / \mathrm{year}$ (taking into account the errors: $2-12 \mathrm{~cm} /$ year) can be calculated for the northward propagation of the first MORB type magmatism in the ocean-continent transition zone. Despite the large uncertainties, this propagation

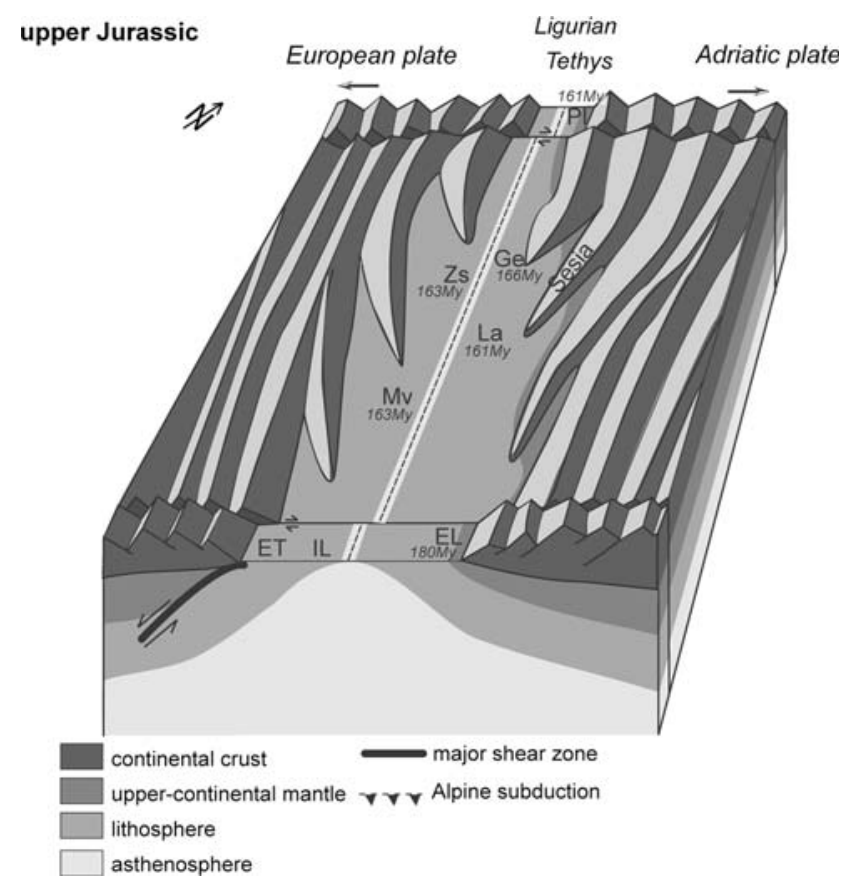

Fig. 10 Proposed schematic paleogeography for the upper Jurassic with the location of the different remnants of oceanic crust, after Dal Piaz (1988), and Péron-Pinvidic (2007). Abbreviations are EL external Liguride, ER Erro-Tobbio, Ge gets nappe, $I L$ internal Liguride, La Lanzo, Mv Monviso, Pl Platta, Zs Zermatt-Saas

velocity is remarkably similar to the $4.4 \pm 0.3 \mathrm{~cm} / \mathrm{y}$ obtained for the Iberia ocean-continent transition (Schärer et al. 2000).

If one considers the age difference of gabbroic intrusions within the Lanzo peridotite $(163 \pm 1 \mathrm{Ma}$, $158 \pm 2 \mathrm{Ma}$ ), and assuming that the paleodistance distance between the different localities does not exceed $25 \mathrm{~km}$, a much lower rate of $\sim 0.5 \mathrm{~cm} /$ year (taking into account the errors: $0.3-0.8 \mathrm{~cm} /$ year) for the propagation of magmatism can be inferred. Although highly speculative, this slow rate is well within the range of ultra-slow spreading rates determined for the Gakkel ridge and the southwest Indian ridge (Dick et al. 2003). This has the interesting consequence that the northward propagation rate of ocean opening is apparently much higher than the inferred spreading velocity itself.

\section{Conclusions}

- The geochemistry of gabbroic dikes from the Lanzo massif indicates a typical MORB type evolution from primitive troctolitic cumulates to highly differentiated Fe-Ti gabbros and plagiogranites.

- Zircon-bearing gabbros have different origins; some of them crystallized within syn-magmatic shear zones, while others are virtually undeformed. The different 
textures correlate with chemistry: the undeformed gabbro represents a cumulate with crystallization of zircon from the intercumulus liquid, while zircon in syn-magmatic shear zones crystallized from evolved liquid that was expelled from a cumulus pile at depth.

- The trace element composition demonstrates that zircon crystallized after substantial plagioclase fractionation. Crystallization temperatures are estimated by $\mathrm{Ti}$-inzircon thermometry to about $800-850^{\circ} \mathrm{C}$.

- $\mathrm{U}-\mathrm{Pb}$ determinations of zircons provide ages between $158 \pm 2$ and $163 \pm 1 \mathrm{Ma}$, consistent with magmatic activity during opening of the Piemont-Ligurian ocean.

- A slow rate of $\sim 0.5 \mathrm{~cm} /$ year is calculated for the propagation of magmatism in the Lanzo massif which is well within the range of ultra-slow spreading rates.

Acknowledgments We thank V. Serneels for helping with the XRF analyses and A. Ulianov for LA-ICP-MS analyses of whole rock glasses. Comments from two reviewers improved the final version of the manuscript. The Electron Microscopy Unit at the Australian National University provided for access to the CL facility. This research was financially supported by the Swiss National Foundation (Project 21-66923.01 and 200020-104636/1).

\section{References}

Aldiss DT (1981) Plagiogranites from the ocean crust and ophiolites. Nature 289:577-578

Beccaluva L, Macciotta G, Piccardo GB, Zeda O (1984) Petrology of lherzolitic rocks from the northern Apennine ophiolites. Lithos 17:299-316

Bill M, Bussy F, Cosca M, Masson H, Hunziker JC (1997) Highprecision $\mathrm{U}-\mathrm{Pb}$ and $40 \mathrm{Ar} / 39 \mathrm{Ar}$ dating of an Alpine ophiolite (Gets nappe, French Alps). Eclogae Geol Helv 90:43-54

Bill M, Nagler TF, Masson H (2000) Major, minor, trace element, $\mathrm{Sm}-\mathrm{Nd}$ and $\mathrm{Sr}$ isotope compositions of mafic rocks from the earliest oceanic crust of the Alpine Tethys. Schweiz Miner Petrog Mitt 80:131-145

Black LP, Kamo SL, Williams I, Mundil R, Davis DW, Korsch RJ, Foudoulis C (2003) The application of SHRIMP to phanerozoic geochronology; a critical appraisal of four zircon standards. Chem Geol 200:171-188

Bodinier JL (1988) Geochemistry and petrogenesis of the Lanzo peridotite body, western Alps. Tectonophysics 149:67-88

Bodinier JL, Guirard M, Dupuy C, Dostal J (1986) Geochemistry of basic dikes in the Lanzo massif (Western Alps): petrogenetic and geodynamic implications. Tectonophysics 128:77-95

Borsi L, Schärer U, Gaggero L, Crispini L (1996) Age, origin and geodynamic significance of plagiogranites in lherzolites and gabbros of the Piedmont-Liguria ocean basin. Earth Planet Sci Lett 140:227-241

Boudier F (1972) Relations lherzolites-gabbro-dunite dans le massif de Lanzo (Alpes Piémontaises): exemple de fusion partielle. In: Institut des $\mathrm{PhD}$ thesis, Université de Nantes, Nantes, p 106

Boudier F (1978) Structure and petrology of the Lanzo peridotite massif (Piedmont Alps). Geol Soc Am Bull 89(10):1574-1591

Boudier F, Nicolas A (1972) Fusion partielle gabbroique dans la lherzolite de Lanzo (Alpes piemontaises). Schweiz Miner Petrog Mitt 52(1):39-56
Bown J, White RS (1994) Variation with spreading rate of oceanic crustal thickness and geochemistry. Earth Planet Sci Lett 121:435-439

Compston W, Williams I, Meyer-Charles E (1984) U-Pb geochronology of zircons from lunar breccia 73217 using a sensitive high mass resolution ion microprobe. J Geophys Res 89:525-534

Compston W, Williams I, Kirschvink JL, Zhang Z, Ma G (1992) Zircon U-Pb ages for the early Cambrian time-scale. J Geol Soc London 149(2):171-184

Coogan LA, Hinton RW (2006) Do the trace element compositions of detrital zircons require Hadean continental crust? Geology 34(8):633-636

Corfu F, Hanchar JM, Hoskin PWO, Kinny P (2003) Atlas of Zircon textures. In: Hanchar JM, Hoskin PWO (eds) Zircon, vol 53. Mineralogical Society of America and Geochemical Society, Washington, pp 469-500

Costa S, Caby R (2001) Evolution of the Ligurian Tethys in the Western Alps: $\mathrm{Sm} / \mathrm{Nd}$ and $\mathrm{U} / \mathrm{Pb}$ geochronology and rare-earth element geochemistry of the Montgenevre ophiolite, France. Chem Geol 175:449-466

Dal Piaz GV (1988) Revised setting of the Piedmont zone in the northern Aosta valley, western Alps. Ofioliti 13(2-3):157-162

Decandia FA, Elter P (1972) La "zona" ofiolitifera del Bracco nel settore compreso fra Levanto e la Val Graveglia (Appennino ligure). Mem Soc Geol It (11):503-530

Desmurs L, Müntener O, Manatschal G (2002) Onset of magmatic accretion within a magma-poor rifted margin: a case study from the Platta ocean-continent transition, eastern Switzerland. Contrib Mineral Petrol 144:365-382

Dick HJB (1994) ODP looks through tectonic windows. JOI/USSAC Newsl 7(2):1-3

Dick HJB, Natland JH, Alt JC, Bach W, Bideau D, Gee JS, Haggas S, Hertogen JGH, Hirth G, Holm PM, Ildefonse B, Iturrino GJ, John BE, Kelley DS, Kikawa E, Kingdon A, LeRoux PJ, Maeda J, Meyer PS, Miller DJ, Naslund HR, Niu Y, Robinson PT, Snow J, Stephen RA, Trimby PW, Worm HU, Yoshinobu A (2000) A long in situ section of the lower ocean crust: results of ODP Leg 176 drilling at the Southwest Indian ridge. In: Earth and planetary science letters, vol. 179, pp 31-51

Dick HJB, Lin J, Schouten H (2003) An ultraslow-spreading class of ocean ridge. Nature 426(6965):405-412

Dietrich VJ (1969) Die Ophiolite des Oberhalbsteins (Graubünden) und das Ophiolithmaterial des ostschweizerischen Molasseablagerungen, ein petrographischer Vergleich, Lang, Bern, p 179

Eggins SM, Rudnick RL, McDonough WF (1998) The composition of peridotites and their minerals; a laser-ablation ICP-MS study. Earth Planet Sci Lett 154(1-4):53-71

Froitzheim N, Schmid SM, Frey M (1996) Mesozoic paleogeography and timing of eclogite-facies metamorphism in the Alps: a working hypothesis. Eclogae Geol Helv 89(1):81-110

Hiess J, Nutman A, Bennett V, Holden P (2006) Ti zircon thermometry applied to metamorphic and igneous systems. Geochim Cosmochim Acta 70(18):A250

Hinton RW, Upton BGJ (1991) The chemistry of zircon: variations within and between large crystals from syenite and alkali basalts xenoliths. Geochim Cosmochim Acta 55:3287-3302

Ionov DA, Savoyant L, Dupuy C (1992) Application of the ICP-MS technique to trace element analysis of peridotites and their minerals. Geostandard Newslett 16:311-315

Jochum KP, Seufert HM, Thirlwall MF (1990) Multi-element analysis of 15 international standard rocks by isotope-disolution spark source mass spectrometry. Geostandard Newslett 14:469-473

Kaczmarek M-A, Müntener O (2005) Exhumation of mantle lithosphere: field relations, and interaction processes between magmatism and deformation (Field trip to the northern Lanzo peridotite). Ofioliti 30(2):125-134 
Kaczmarek M-A, Müntener O (2007) Juxtaposition of melt impregnation and high temperature shear zone in the upper mantle (Lanzo peridotite, N-Italy) I: textures and minerals composition. J Petrol (submitted)

Kienast JR, Pognante U (1988) Chloritoid-bearing assemblages in eclogitized metagabbros of the Lanzo peridotite body (western Italian Alps). Lithos 21(1):1-11

Koepke J, Feig ST, Snow J (2005) Hydrous partial melting within the lower oceanic crust. Terra Nova, 17:286-291

Lagabrielle Y, Fudral S, Kienast J-R (1989) La couverture océanique des ultrabasites de Lanzo (Alpes Occidentales): arguments lithostratigraphiques et pétrologiques. Geodinamica Acta $4(1): 43-55$

Langmuir CH, Klein EM, Plank T (1992) Petrological systematics of mid-ocean ridge basalts: Constraints on melt generation beneath ocean ridges. In: Phipps Morgan J, Blackman DK, Sinton JM (eds), Mantle flow and melt generation at mid-ocean ridges, Geophysical Monograph Series, vol. 71, AGU, Washington DC, pp. $183-280$

Lombardo B, Rubatto D, Castelli D (2002) Ion microprobe U-Pb dating of zircon from a Monviso metaplagiogranite: implications for the evolution of the Piedmont-Liguria Tethys in the western Alps. Ofioliti 27(2):109-117

Ludwig KR (2003) Isoplot/Ex version 3.0. A geochronological toolkit for Microsoft Excel. Berkeley Geochronological Centre Special Publication

Müntener O, Piccardo GB (2003) Melt migration in ophiolitic peridotites: the message from Alpine-Apennine peridotites and implications for embryonic ocean basins. In: Dilek Y, Robinson PT (eds) Ophiolites in earth history, vol. 218. Geological Society of London, London, pp 69-89

Müntener O, Manatschal G (2006) High degrees of melting recorded by spinel harzburgites of the Newfoundland margin: the role of inheritance and consequences for the evolution of the southern North Atlantic. Earth Planet Sci Lett 252:437-452

Müntener O, Piccardo GB, Polino R, Zanetti A (2005) Revisiting the Lanzo peridotite (NW-Italy): 'asthenospherization' of the ancient mantle lithosphere. Ofioliti 30(2):111-124

Nicolas A (1989) Structures of ophiolites and dynamics of oceanic lithosphere, vol. 4. Kluwer, Dordrecht, p 367

Ohnenstetter M, Ohnenstetter D, Vidal P, Cornichet J, Hermitte D, Mace J (1981) Crystallization and age of zircon from Corsican ophiolitic albitites: consequences for oceanic expansion in the Jurassic times. Earth Planet Sci Lett 54:397-408

Pearce NJG, Perkins WT, Westgate JA, Gorton MP, Jackson SE, Neal CR, Chenery SP (1996) A compilation of new and published major and trace element data for NIST SRM 610 and NIST SRM 612 glass reference materials. Geostandard Newslett 21(1):115144

Pelletier L (2003) Relation entre une croûte océanique et sa couverture sédimentaire. L'exemple du massif de Lanzo (Alpes piémontaises, Italie). In: Diplôme de Géologie BENEFRI, vol., Neuchâtel

Pelletier L, Müntener O (2006) High pressure metamorphism of the Lanzo peridotite and its oceanic cover, and some consequences for the Sesia-Lanzo zone (northwestern Italian Alps). Lithos 90:111-130

Péron-Pinvidic G, Manatschal G, Minshull TA, Sawyer DS (2007) The tectono-sedimentary evolution of the deep Iberia-Newfoundland margins: evidence for a complex break-up history. Tectonics, 26

Piccardo GB (1976) Petrologia del massiccio lherzolitico di Suvero (La Spezia). Ofioliti 1:279-317

Piccardo GB, Müntener O, Zanetti A (2004) Alpine-Apennine ophiolitic peridotites: new concepts on their composition and evolution. Ofioliti 29(1):63-74
Piccardo GB, Zanetti A, Müntener O (2007) Melt/peridotite interaction in the Lanzo South peridotite: field, textural and geochemical evidence. Lithos 94(1-4):181-209

Pognante U (1989) Lawsonite, blueschiste and eclogite formation in the southern Sesia zone (western Alps, Italy). Eur J Miner 1:89104

Pognante U, Rösli U, Toscani L (1985) Petrology of ultramafic and mafic rocks from the Lanzo peridotite body (western Alps). Lithos 18:201-214

Puschnig AR (1998) The Forno unit (Rhetic Alps): evolution of an ocean floor sequence from rifting to Alpine orogeny. $\mathrm{PhD}$ thesis, ETH Zürich

Rampone E, Hofmann AW, Raczek I (1998) Isotopic contrast within the internal liguride ophiolite (N. Italy): the lack of a genetic mantle-crust link. Earth Planet Sci Lett 163:175-189

Reddy SM, Timms NE, Trimby PW, Kinny PD, Buchan C, Blake K (2006) Crystal-plastic deformation of zircon: a defect in the assumption of chemical robustness. Geol Soc Am 34(4):257-260

Roeder PL, Emslie RF (1970) Olivine-liquid equilibrium. Contrib Mineral Petrol 29:275-289

Rubatto D, Gebauer D (2000) Use of cathodoluminescence for U-Pb zircon dating by ion microprobe; some examples from the Western Alps. In: Pagel M, Barbin V, Blanc P, Ohnenstetter D (eds) Cathodoluminescence in geosciences, Springer, Berlin, pp 373-400

Rubatto D, Hermann J (2003) Zircon formation during fluid circulation in eclogites (Monviso, Western Alps): Implications for $\mathrm{Zr}$ and $\mathrm{Hf}$ budget in subduction zones. Geochim Cosmochim Acta 67(12):2173-2187

Rubatto D, Gebauer D, Fanning M (1998) Jurassic formation and Eocene subduction of the Zermatt-Saas-Fee ophiolites: implications for the geodynamic evolution of the Central and western Alps. Contrib Mineral Petrol 132:269-287

Sandrone R, Leardi L, Rossetti P, Compagnoni R (1986) P-T conditions for the eclogitic re-equilibration of the metaophiolotes from Val d'Ala di Lanzo (internal Piemontese zone, Western Alps). J Metamorph Geol 4:161-178

Schaltegger U, Desmurs L, Manatschal G, Müntener O, Meier M, Frank M, Bernoulli D (2002) The transition from rifting to seafloor spreading within a magma-poor rifted margin: field and isotopic constraints. Terra Nova 14:156-162

Schärer U, Girardeau J, Cornen G, Boillot G (2000) 138-121 Ma asthenospheric magmatism prior to continental break-up in the north Atlantic and geodynamic implications. Earth Planet Sci Lett 181(4):555-572

Serri G (1980) Chemistry and petrology of gabbroic complexes from the northern Apennine ophiolites. In: Panayiotou A (ed) Ophiolites; proceedings, international ophiolite symposium, pp 296-313

Stacey JS, Kramers JD (1975) Approximation of terrestrial lead isotope evolution by a two-stage model. Earth Planet Sci Lett 26(2):207-221

Sun SS, McDonough WF (1989) Chemical and isotopic systematics of oceanic basalts: Implications for mantle composition and processes. In: Sanders AD, Norry MJ (eds) Magmatism in the ocean basins, vol. 42. Special Publication Geological Society of London, London, pp 313-345

Timms NE, Kinny PD, Reddy SM (2006) Enhanced diffusion of uranium and thorium linked to crystal plasticity in zircon. Geochem Trans 7(10)

Tribuzio R, Thirlwall MF, Vannucci R (2004) Origin of the gabbroperidotite association from the northern Apennine ophiolites (Italy). J Petrol 45(6):1109-1124

Tucholke BE, Sawyer DS, Sibuet JC (2007) Breakup of the Newfoundland-Iberia rift. In: Karner GD, Manatschal G, Pinheiro L (eds), Imaging, mapping and modeling continental 
lithosphere extension and breakup, geological society of London, Special Publication, vol. 282

Watson EB, Harrison TM (2005) Zircon thermometer reveals minimum melting conditions on earliest earth. Science 308:841-844
Watson EB, Hayden LA, Wark DA, Cherniak DJ, Thomas JB, Manchester JE (2006) New crystallization thermometers for zircon, rutile and sphene; calibrations, diffusion considerations, and applications. Geol Soc Am 38(2):5 